\title{
Transformation of Socialist Realistic Residential Architecture into a Contemporary Sustainable Housing Habitat-General Approach and the Case Study
}

\author{
Maciej Piekarski ${ }^{1, *(D)}$, Łukasz Bajda ${ }^{2}$ and Ewelina Gotkowska ${ }^{1}$ \\ 1 Department of Architectural Design and Engineering Graphics, Faculty of Civil and Environmental \\ Engineering and Architecture, Rzeszow University of Technology, 35-959 Rzeszow, Poland; \\ egotkowska@prz.edu.pl \\ 2 Department of Town Planning and Architecture, Faculty of Civil and Environmental Engineering and \\ Architecture, Rzeszow University of Technology, 35-959 Rzeszow, Poland; lb@prz.edu.pl \\ * Correspondence: mgpiekar@prz.edu.pl
}

check for updates

Citation: Piekarski, M.; Bajda, Ł.; Gotkowska, E. Transformation of Socialist Realistic Residential Architecture into a Contemporary Sustainable Housing Habitat-General Approach and the Case Study. Sustainability 2021, 13, 13486. https:// doi.org/10.3390/su132313486

Academic Editors: Nađa Beretić, Arnaldo Cecchini and Valentina Talu

Received: 29 October 2021

Accepted: 1 December 2021

Published: 6 December 2021

Publisher's Note: MDPI stays neutral with regard to jurisdictional claims in published maps and institutional affiliations.

Copyright: (c) 2021 by the authors. Licensee MDPI, Basel, Switzerland. This article is an open access article distributed under the terms and conditions of the Creative Commons Attribution (CC BY) license (https:/ / creativecommons.org/licenses/by/ $4.0 /)$.

\begin{abstract}
This article deals with the problem of multi-family housing implemented in the 1950s in Poland. Buildings from this period are located in the central districts of cities, and are wellconnected and equipped with service infrastructure, but due to the small size of these flats, their low standard and poor technical condition, they are not sufficiently attractive for middle-class people and developing families. The consequence of this is the social selection of residents and the disappearance of neighborly relations. In this article, the authors present a balance sheet of the shortcomings and advantages of these buildings, and against the background of contemporary requirements for housing, resulting from the theory of sustainable development, they indicate possible directions for modernization. Detailed solutions are presented for a specific housing complex located in Rzeszów. The development of flat roofs and the introduction of functions integrating the community of residents are the significant elements of the project. Due to the fact that the functional layouts of stories, the structure of buildings, and to a large extent the spatial arrangement of residential complexes were unified in the 1950s throughout the whole country, the presented concept may serve as inspiration for similar projects undertaken in any other city in Poland.
\end{abstract}

Keywords: housing; socialist realism; sustainable development; revitalization; modernization

\section{Introduction}

Cities are urban and social structures. Meeting the housing needs of residents is one of the basic functions of the city. The changes related to the fulfillment of this function result in city transformation. A new housing stock is being built, while the demolition and modernization of existing buildings are also being carried out. The transformation of the housing resources results in demographic changes within the city. In cities with a small or even negative population growth, the increase in the housing stock results from the aspirations of residents seeking to exchange their existing flats for ones which are larger, better equipped or more conveniently located. In the countries of Eastern Europe, the effect of these aspirations, overlapping with the loosening of the spatial planning discipline, is mass suburbanization [1]. The result of migration to new housing built on the periphery is the depopulation of districts closer to the center.

Older town quarters are usually well-equipped with supporting infrastructure, such as schools, kindergartens, clinics, shops, etc. The public transport network is dense, and many destinations are within walking distance. The concept of a 20-min city [2] is easy to implement in such conditions. The weakening of the housing function in these districts is unfavorable for the city as a whole. It leads to the necessity to duplicate this infrastructure in new districts, and intensifies transport problems. Social selection is thus taking place in 
cities. As a result, the social spectrum of the center's inhabitants narrows down to older people, who do not plan to improve their housing conditions, and young people, who buy flats which are less comfortable and in a worse technical condition due to their low prices. None of these groups, for various reasons, consider the current place of residence in a long-term perspective. The shortness of the perspective of living is not conducive to social involvement and impoverishes interpersonal relations. The ring of buildings surrounding the very center of the city becomes an area of "inner periphery" [3], which weakens the city's unity and lowers the feeling of community among its inhabitants.

This article concerns multi-family housing from the 1950s in Poland, which is part of the residential environment of Polish cities, corresponding to the above characteristics. The specificity of this housing results from the political and economic conditions that influenced the form of construction and architectural solutions and their repeatability throughout the country. The authors defined the scale of the stock in question against the background of the total volume of flats in Poland and the rate of its increase in the last 30 years. They identified the functional and utilitarian features of these buildings that weaken their modern attractiveness and indicated the values constituting the modernization potential of these buildings. They presented concepts for architectural and construction solutions that transform buildings into modern sustainable residential environments.

The issue of the spatial modernization of multi-family residential buildings erected in Poland in the 1950s with the superposition of contemporary features over historical ones has not been discussed in the scientific literature. The projects incidentally realized included the adaptation of buildings in a narrow scope and were not based on an indepth analysis. The assumed goal of this article is to initiate a discussion in the scientific community, also involving public or commercial entities operating on the development market, in order to generate interest in the modernization potential of this specific part of the housing stock. Due to the similarity of housing problems in post-socialist countries, both in the period of the development of the housing stock in question and in the last 30 years, the authors hope that this article will also arouse the interest of readers outside of Poland.

\section{Research Motivation, Materials and Methods}

The direct cause of the authors' interest in the research topic is living in a city where, as a result of the first stage of intensive development in the 1950s, there are a relatively large number of multi-family residential buildings from that period, and in connection with the currently intensive next stage of housing development, the flats within them are devoid of competitiveness. First, the authors decided to find out to what extent this situation is typical of the condition of housing in Poland and to determine its scale. They conducted an analysis of statistical data, legal acts, documents and scientific literature in order to determine the specific features of multi-family housing in the 1950s and the size of the stock created in that period against the background of changes in the general volume of multi-family housing resources in Polish cities and changes in the ownership structure. The established view was confronted with the available information on the condition of housing in other post-socialist countries and the rest of the EU.

As the overriding goal of the authors was to diagnose the possibility of adapting the housing stock in question to the requirements of modern housing and to identify specific modernization concepts, the main theories of housing formulated after the 1950s were analyzed. Particular attention was paid to postulates based on the concept of sustainable development, as well as on relations between the spatial arrangement of housing complexes and the social integration of residents at the neighborhood level. Adequate examples of actual solutions implemented in housing construction with characteristics similar to that consideration were searched. The potential of the residential complexes was determined on the basis of the preserved designs, our own observation and general orientation resulting from personal experience and contacts with their residents, owners, administrators, etc. The Google Maps platform was used to assess the similarity and differences in spatial layouts 
of buildings in different cities. The directions of transformation were determined by means of rational deduction and the authors' experience in architectural and construction design.

The authors considered the conceptual design of the transformation of a specific residential complex to be the correct way to prove the theses put forward in the descriptive part of this article. As the subject of the case study, such a housing complex was selected, the complexity and compactness of which allowed for the implementation of a wide range of modernization ideas. Its location in the authors' city of residence facilitated multiple on-site observations. The design is not a response to specific plans to modernize this complex, but only a suggestion for researchers, designers, as well as private and public developers in terms of the directions of using the potential of multi-family residential buildings of the socialist realism period. The general scheme of the research carried out is presented in Figure 1.

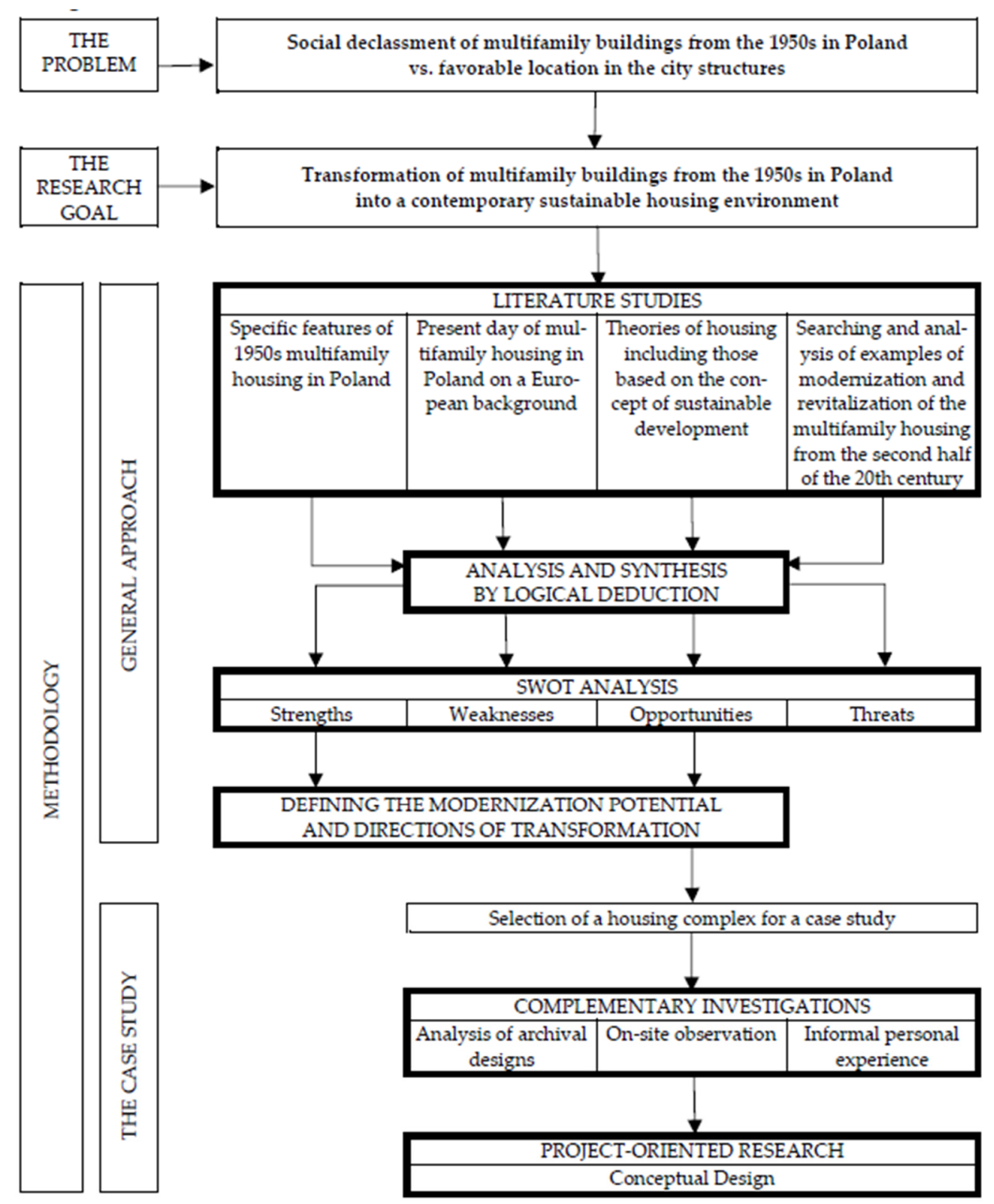

Figure 1. The scheme of the research carried out.

\section{Literature Research Report}

\subsection{Multi-Family Housing in the 1950s in Poland}

The architecture of the 1950s was governed in Poland by a style known as socialist realism. The most recognizable feature of this was the monumental architectural form 
referring to historical tradition. According to the assumptions formulated by political authorities, architecture had to be "socialist in content and national in form" [4]. Contrary to appearances, architects were left with quite a lot of creative freedom. The socialist content of housing architecture very often meant a continuation of trends that had started before World War II. The result was housing quite decent both in the quality of the flats and the neighborhood, which did not deviate from Western European standards at the time [5]. As for the form, the influence of ideological assumptions has been observed only in the buildings of the most representative parts of the cities [6]. There was neither financial nor time availability for full compliance with the guidelines. The period of the 1950s in Poland was characterized by dynamic urbanization related to the development of industrial centers and the mass migration of people from the countryside to the cities. The demand for new apartments was huge. Moreover, the reconstruction of building damaged by war was still in progress.

Multi-family housing construction was carried out exclusively by public entities. The size of the apartments was strictly regulated by the housing standard. According to the decree of the Minister of Municipal Economy of 1951 [7], there should be $9-12.5 \mathrm{~m}^{2}$ of usable floor space per person in an apartment, while for some categories of people, it was only 6-9 $\mathrm{m}^{2}$. This regulation was in force until 1958. In 1954, the regulation of sizes of flats was introduced [8], according to which the area of a one-room flat should be $18-22 \mathrm{~m}^{2}$, that of a two-room flat should be $28-39 \mathrm{~m}^{2}$, that of a three-room flat should be $41-50 \mathrm{~m}^{2}$, that of a four-room flat should be $51-58 \mathrm{~m}^{2}$, and that of a five-room flat should be $59-66 \mathrm{~m}^{2}$. In buildings equipped with central heating, which was already common at that time, the lower limits of the above-mentioned norms were recommended. The structure of flats completed in public housing in 1955 was as follows: $5.1 \%$ were one-room flats, $23.6 \%$ were two-room flats, $59.7 \%$ were three-room flats, and $11.6 \%$ were flats with four or more rooms [9]. The notion of a room in this period meant a room in the classic sense, as well as a separate kitchen lit by daylight. Based on the above-mentioned data, it can be calculated that the average area of a newly built flat was approx. $43 \mathrm{~m}^{2}$, and there were 2.8 rooms per flat.

From 1949 onwards, one nationwide institution, called Zakład Osiedli Robotniczych (Workers' Housing Estate-ZOR), with its own design office was responsible for the design and implementation of housing in cities [10]. The dominant type of designed building was a cage house with three or four flats accessible from the landing [6]. The buildings, with the exception of those erected in representative districts of large cities, generally had four residential floors and were not equipped with elevators. They were erected using masonry technology with the implementation of partially prefabricated floor structures. The longitudinal arrangement of structural walls was dominant due to the possibility of using the same material for the structure and thermal insulation of the building. The combination of all these circumstances resulted in the extreme unification of the functional layouts of apartments. The problem regarding the lack of housing in cities and the methods of solving this issue were also similar in the early post-war period in other countries of Central and Eastern Europe, e.g., in the former Yugoslavia [11].

In total, in the years 1949-1955, ZOR designed and implemented at least 210,000 apartments throughout Poland [9]. This number is not significant compared to the size of the entire housing stock in cities in Poland, amounting in 2020 to over 10 million apartments [12]; however, assuming that a certain number of apartments designed by ZOR were commissioned in the years after 1955 [13], it is comparable to the two-year increase in the housing stock in cities in Poland in 2019-2020, amounting to 290,000 apartments [12].

\subsection{Contemporary Context}

Comparing the data from 1955 with the data from 2019 leads to a partially paradoxical conclusion that the size of apartments currently being built in Poland is similar to that in 1955. The statistical data [12] show that a new apartment built in 2020 in a city in a multi-family building had an average of 2.9 rooms. This paradox results from the fact 
that nowadays, the kitchen is usually not designed as a separate room, but as part of a living room. The number of rooms in apartments built in 1955 meant the sum of rooms in the strict sense and the kitchen, while now it is generally equal to the number of rooms. However, the average area of a flat completed in 2019 was $61.0 \mathrm{~m}^{2}$, i.e., over $40 \%$ more than in the period of the 1950s. The overall increase in the housing standard is also confirmed by other figures. According to data collected in censuses, in 1950, there were 1.5 people per one room in cities [9], while in 2011, this figure was 0.75 people [12]. The comparison of statistical data and the self-conducted observation of the housing market authorize the authors to conclude that apartments from the 1950s are currently insufficiently attractive for families consisting of young or middle-aged people bringing up children. Despite the lack of statistical data on the equipping of apartments with balconies and elevators, the general knowledge proves that the difference in this respect between old and new apartments is significant and also differentiates the attractiveness of them.

Reproduction of the same or analogous architectural solutions throughout Poland mobilize the search for methods of modernization of multi-family buildings from the 1950s, because they will also be able to be duplicated. The modernization of buildings in order to change the area structure of flats and equip them with devices which serve to increase the comfort of living requires significant interference in the building substance. Therefore, it should be considered in a broader context, as a transformation responding to the postulates of all later theories on the housing environment, including those that fit into the context of sustainable development.

The circumstances objectively limiting the possibilities of modernization are ownership relations and considerations of a conservation nature. Despite the fact that the buildings were erected by public bodies, they survived as fully communal properties only until the 1980s. The first legal act enabling privatization was prepared in 1985 [14]. The privatization process was commenced on a large scale after 1989. Individual flats were given the status of separate real estate, and sales to existing tenants began. Persons with a long tenure of residence were granted discounts of up to $80 \%-95 \%$ [15], which made the purchase offer extremely profitable. Initially, the land under the buildings remained communal property leased to the owners of the flats in the buildings standing on them. The right of perpetual usufruct of land was also transformed into ownership under the 2018 act [16].

Statistical data do not document the scale of ownership transformations of dwellings which were built within the analyzed period. This trend is evidenced by general data on the share of council flats in the total housing stock. In 2002, it was 15.8\% [15], in 2011, it was $8.9 \%$ [15], and in 2019, it was only 3.4\% [12]. The percentage indicators do not accurately reflect the scale of privatization of council flats, as the period covered by the above-mentioned dates was characterized by an approx. $20 \%$ increase in the total housing stock, but among new flats, communal flats constitute only $1 \%$ [12]. It is notable that in a country where, in the recent past, socialized property was dominant, the percentage of communal housing is much lower than in some countries that did not go through the stage of the socialized economy in their history. For comparison, in the Netherlands, the percentage of municipal housing is $29 \%$, in Austria it is $24 \%$, in Denmark it is $21 \%$, in Sweden it is $17 \%$ and in France it is 16\% [17].

The distinctness of the situation in city housing in Poland and other post-socialist countries compared to other EU countries is also expressed by differences in the ratios of flats to individual houses and owners to tenants. In eight out of the eleven post-socialist countries that are EU members, the percentage of flats is higher than the average rate for the entire EU, amounting to $71.7 \%$, including $77.1 \%$ in Poland [18]. In all 11 of these countries, the ratio of owners exceeds the average for the EU, amounting to $69.8 \%$, and in Poland, it is $84.2 \%$ [18]. The differences between these eleven countries and the rest of the EU are the result of the privatization of the existing housing stock left over from the previous epoch's preference for multi-family housing and the dynamics of housing construction in the last thirty years. In Poland, over the years 1988-2020, the number of flats in cities increased 
from 7 to over 10 million [12], so by over $40 \%$. Almost all of these flats have been built with the population's own resources. A similar dynamics of the development of housing is typical for other countries in Central and Eastern Europe. The number of residential building permits related to the population issued in the period 2015-2019 exceeds the EU average in seven out of the eleven countries under consideration [18]. The quoted facts support the similarity of the housing situation in the post-socialist countries and its distinctiveness compared to the situation in Western Europe.

The policy of donating the public housing stock to the population, common in all countries of Central and Eastern Europe, was favorable due to the possibility of the quick enrichment of the pauperized society. However, it not only serious transformations of buildings difficult, but also caused issues with carrying out the repairs necessary due to their poor technical condition [19]. The insulation of the outer walls of buildings turned out to only be quite efficient, because it did not require conducting works inside the apartments, and moreover it was financially subsidized from public funds. Worn or obsolete internal installations were replaced to a lesser extent [20]. Few buildings have been extended, and few have been retrofitted with elevators, which are usually external. The scope of the undertaken activities was limited by the individual ownership of individual apartments and their occupation during renovation. The revitalization of the post-socialist housing environment more often involved spaces between buildings than the buildings themselves. Small accompanying buildings, especially those of low aesthetic value, were demolished, undeveloped spaces were filled with new objects, trees and plants were planted, and recreation areas, especially for children, were constructed in the spaces between the blocks [21]. The revitalization of the buildings themselves mainly included objects of an older origin, being classified as monuments, with public, industrial or office functions, and very rarely residential [22].

The problem of the individual ownership of apartments in multi-family buildings is an obstacle both in the process of revitalization, understood as the improvement of the material quality of buildings, and gentrification, understood as socio-demographic changes resulting from the involvement of new capital [23,24]. Carrying out the large-scale modernization of post-socialist housing turned out to be much easier in the area of the former East Germany, because after the reunification of Germany, a significant portion of the inhabitants left to the western part of the country. They left their apartments and declined to offer to purchase them as property [25]. In eastern Germany, some multi-family buildings from the GDR period were even demolished [26], which, in view of the demand reduced by migration, did not cause any noticeable damage to the supply of flats. In other countries, such as Russia [27] and Vietnam [28], projects to demolish the existing buildings and replace them with new ones built in similar locations have been undertaken. As they concerned inhabited buildings, they were not welcomed by the residents who were offered re-housing, even though they were to be financed from public funds. Although the intention of the originators was to improve the image of the housing estates, which has changed for the worse compared to the original condition, it turned out that old buildings are a carrier of local identity, which residents do not want to lose.

When starting the study, the authors assumed that they could disregard the ownership situation of flats and buildings, because taking it into account would practically exclude architectural and construction considerations, reducing them to the legal and economic level. On the contrary, they recognized that a rational proposal for spatial transformations may be an impulse for specialists from other fields that would initiate the search for relevant organizational solutions and conducting economic calculations. The authors believe, from the general orientation in the housing market in Poland, that a significant portion of flats in buildings from the 1950s do not serve to meet the personal housing needs of their current owners, but are flats intended for rent. The situation varies depending on location.

The matter of the conservation of approximately 70-year-old buildings and housing complexes is highly diversified. Only a few buildings are entered into the register of monuments, which is a higher form of protection. This is due both to the significant 
diversity of architectural forms, as well as the fact that the institutions of conservation protection are decentralized in Poland, and hence the approach to protecting relatively new objects is different in different regions. Strict protection usually covers urban layouts and architectural forms of buildings situated along the representative streets and squares of larger cities [29]. With reference to the flagship embodiment of socialist realist architecture, which was the city, and now a district of Krakow, Nowa Huta, there are even efforts for it to be entered into the UNESCO World Heritage List [30]. Buildings of less value, most often located in less exposed places or in smaller cities, are not protected, or are entered into the municipal register of monuments, which only slightly restricts the freedom of modernization of these buildings. As for the conservation protection of 20th-century objects, specialists postulate maintaining a balance between protecting all of them and the protection of nothing. The artistic, scientific and historical value of each object should be assessed individually [31]. This approach leaves space for conceptual work on the transformation of socialist realist housing complexes into living environments meeting contemporary theories of housing.

\subsection{Sustainable Housing Environment-Theories and Patterns}

The authors set the goal for themselves of finding ways not only to transform buildings, with the aim of raising the standard of the flats, but also to supplement common infrastructure, in order to make the residential complex an environment integrating the community of residents. A good basis for searching the means for the realization of this goal are theories formulated far before the end of the 20th century in books: The Death and Life of America's Great Cities [32] by Jane Jacobs and The Language of Patterns-Cities, Buildings, Construction [33] by Christopher Alexander. The first book deals with issues set in the scale of the street, district and the entire city, but one can also find the insights relevant from the point of view of a residential complex. Alexander's book is a comprehensive compendium of architectural and urban knowledge.

Jacobs' references to "new ideas need old buildings" and "one of the most admirable and enjoyable sights we can enjoy on the streets of large cities is the ingenious conversion of old buildings for new purposes" [32] serve as the obvious motivation for taking up the job described in this article. Jacobs points out that designing cities with the thought of only a nuclear family is a mistake. She describes social isolation as the greatest environmental risk associated with living in a city.

Alexander associates the lack of involvement of people living in blocks of flats in public life with a lack of semi-private space, going beyond the flat, but not being public space. The significance of the division of space into private, semi-public and public is also emphasized in Jan Gehl's later work [34]. Alexander emphasizes the importance of intergenerational diversity in the living space, as well as the importance of cafés and grocery stores as factors strengthening the identity of the neighborhood. He pays attention to unused roof surfaces. He believes that the roof should be a useful space which people would be in contact with every day. He recommends keeping small rooms in the living space, where people from the neighborhood can work on their own. He suggests that the common spaces should be shaped so that they force the greatest possible movement, the greatest number of mutual contacts and observing the activities of other people, because "the view of the action is an incentive to act" [33].

Most of the opinions cited have been confirmed in later town planning manifestos. In the New Athens Charter [35] accepted in 1998, attention was drawn to, inter alia, the key role of a building complex as a framework for people-to-people contacts, the need to mix functions in housing complexes and diversify the housing offer, as well as such designs that would recreate a sense of community and social care. The revision of this charter in 2003 [36] again drew attention to the renewal of ties between generations and social solidarity.

The concepts of the future functioning of society related to the issues of construction, architecture and urban planning in documents and publications published since the end of 
the 20th century refer verbally and substantially to the concept of sustainable development, which was formulated in The Bruntdland Report in 1987 [37]. The principle of meeting the needs of the present generation without compromising the ability of future generations to meet them could be interpreted in terms of architecture directly as an imperative to design facilities adaptable to human needs and aspirations that change over time. However, the concept of sustainable development was soon expanded. In 1995, Adil Kahn highlighted three sub-areas: society, economy and environment [38], for which the concept of sustainable development was then defined in more detail, including architectural and urban aspects.

With regard to urban issues, the 15 principles of green urbanism formulated by Steffen Lehmann [39] are noteworthy. The concept of sustainable architecture has emerged as a determinant of sustainable social development. Architecture is sustainable if creates spaces that force social interactions, contributes to building the identity of users, provides a sense of security, is adaptable, and is socially inclusive thanks to the fact that it creates conditions for undertaking various activities [40]. A built environment characterized by these features has a chance to become a one in which the present inhabitants will want to live and work not only now, but also in the future [41].

The extensive guidelines for designing a development were presented by David Rudlin and Nicholas Falk [42]. One of their postulates is designing architectural and urban structures so that they naturally force the formation of local communities, based not on the similarity of interests or social status, but on co-presence in the same space. Communities should be diverse, including in terms of age, material status, ethnic criterion, and this is possible thanks to, for example, mixing apartment owners and renters in one area. Measures such as the limitation of parking spaces, mixing work/home functions in architectural units, introducing greenery in the immediate vicinity of apartments, including urban agriculture, local energy production, etc., are postulated.

Urban agriculture has become one of the new trends in architecture. Roof crops are promoted as an essential component. Green roofs have started to be designed not only in new buildings, but also the roofs of existing buildings are being replaced with green ones. They are diversified in terms of the main aim of roof construction and the way of growing plants [43], depending on the thickness of soil substrate [44]. Thick substrates create an opportunity for more diverse crops, but due to the heavy weight of soil saturated with rainwater, they are not suitable for use on the roof of a building, the structure of which is not prepared to withstand large additional loads.

Plants can be grown in soil that is laid on a permeable layer directly on the roof surface, or in boxes. Laying a layer of soil on the roof improves the thermal comfort of the rooms on the top floor [45]. In the summer months, the internal temperature can thus drop by as much as $5-7{ }^{\circ} \mathrm{C}$ [46], but this solution requires proper preparation of the roof covering. In the simplest solutions with the use of boxes, if the roof is accessible and the roofing is sufficiently durable, the boxes or planters can be placed directly on top of the existing roofing $[47,48]$. The bottoms of the boxes must ensure the drainage of excess water, or they can be adapted to collect it, so that in rainless weather, plants can use it by capillary action [49]. Each time, the roof structure should be checked and possibly redesigned so that it is able to bear additional load from the weight of plants, soil, water, boxes and people on the roof. Apart from soil cultivation, hydroponic cultivation is recommended [50]. The advantage of hydroponic cultivation may be a lower load on the roof structure, which is especially important for a roof on an already existing building.

Besides the ability to produce food directly in the place of residence, cultivation on the roofs of multi-family buildings provides benefits by integrating residents and educating people who, due to living in city centers and a lack of access to private land, would otherwise not have contact with cultivation in their own garden [43,51]. The crops can be part of a wider roof management strategy, including, inter alia, furnishings with garden furniture, rooms for individual office work, gyms or spaces for residents to share their passions [52]. One of the arguments for locating a recreational function on a green roof is the positive microclimate. It has been proven that green roofing lowers 
the perceived temperature by up to $11^{\circ} \mathrm{C}$ [46], and it can be as much as $4{ }^{\circ} \mathrm{C}$ lower than the temperature at street level [53]. Additionally, the impact of air pollutants common in the urban environment is lower on the roof than at the ground level [54]. This provides advantages both for people who take recreation on the roof, and for the quality of the cultivated plants, especially vegetables and fruits. Greenery on the roof is perceived as being more socially accessible compared to large-scale parks or urban forests, as these are often organized away from housing estates, especially those located in city centers [55]. Moreover, the space located high above the street level is less polluted with noise.

Plant cultivation, recreation and possible rainwater harvesting and storage to irrigate vegetation during rainless weather are not the only benefits that the roof can provide to the environment and humans. The use of the roof surface to produce electricity with the help of photovoltaic panels is quite common, but in general, it is not combined with the simultaneous use of the roof for other utility functions. Stefan Sattler, Irene Zluwa and Dorris Österreicher presented the development of the roof of one of the buildings of the University of Natural Resources and Life Sciences in Vienna, where translucent photovoltaic panels were used, including some with holes, mounted on a wooden pergola set on the roof [56]. Boxes with plants and garden furniture were placed under this roof, in this way creating a place for recreation. The structure of the pergola was additionally used as a trellis for climbing plants. The panels generate electricity, constitute the roof, and the applied solution provides both access to sunlight for plants and irrigation with rainwater. Sattler et al., based on the experience gained from this installation, presented the concept of analogous steel pergolas, analyzing in detail the design aspects, collection and use of rainwater, energy issues, etc.

The present state of development of photovoltaics makes it possible to combine the function of generating electricity with another utility function in the same structural element of the building. Producers offer, among other things, one- and two-chamber glazing units, self-snow removal modules, movable sun visors, ventilated facades, balustrades or heating panels with built-in photovoltaic cells [57]. From the point of view of the possibility of constructing the superstructure of the existing building, the use of self-snow removal modules creates an opportunity to use part of the load-bearing capacity of the building structure, which results from the ability to transfer the snow load, to transfer the dead load resulting from the superstructure. In addition, it allows one to not only create seasonal open gardens on the roof, but also greenhouses used for year-round plant cultivation, heated and illuminated with energy obtained from photovoltaic cells.

Cells mounted on facades can provide additional benefits. Wall cells, mounted parallel to the wall surfaces, generally provide less energy than roof cells, which is due to the acute angle of sunbeams, but their advantage is trouble-free operation during the snow cover period. The energy yield may be increased if the PV modules are mounted in positions other than vertical [58]. Nowadays, the function of generating electricity is available even in flexible materials [59] and those that do not differ in appearance from traditional materials, e.g., tiles, paving panels [60], etc. The designer can select the photovoltaic material that fits with the intention of preserving the original character of an architectural form or the radical change of this form towards overwriting contemporary values.

\section{Modernization Potential and Appropriate Transformation Directions}

\subsection{Architectural and Urban Characteristics}

The characteristics of apartments in multi-family buildings from the 1950s are presented in Section 3.1. As for the characteristics of the buildings as a whole, they have a basement, and on the basement level, apart from individual storage rooms, there are common rooms, originally intended for, among other things, laundries and drying rooms, but are not currently used for this purpose. As the buildings were designed at a time when the memory of World War II was still alive and the threat of another war was actually considered, the basement rooms were been designed in part as air raid shelters. They have a reinforced structure, toilets, vestibules serving as lockers and emergency exits leading 
outside the building. The rule that, despite the fact that buildings were equipped with central heating systems, each apartment had to have a solid fuel fireplace, was another effect of the threat of war. As a result, there are a large number of chimneys in the buildings, and they occupy a large part of their cubature and a large part of the roof area. The roofs of the buildings are flat. The structural walls are arranged longitudinally for savings in building materials, while fulfilling structural and insulating functions. Transverse walls, including those separating individual apartments, are thin. Due to the fact that they are made of brick, they do not provide the apartments with sufficient acoustic comfort.

Buildings usually form compact housing complexes. This is partially a result of the rejection of the loose building paradigm, which was then in force in Western urban planning, as ideologically alien. The willingness to use the area to the maximum level was also important, as was the military advantage of compact buildings as being more convenient for defense. The frontage buildings of representative streets and squares are characterized by monumental forms. Buildings situated perpendicular to the streets and situated in closed or semi-open urban interiors created by frontage buildings are generally free from architectural details devoid of utility. The ground floors of buildings located along the main streets are intended for services, and therefore the entrances to apartments in such buildings and the access roads to them are from the courtyards. Arcades are a frequent element, especially in places that are the most representative. For reasons of composition, the frontages along the main streets are situated away from the road by a considerable distance.

The urban interiors of individual residential complexes are covered with greenery, including tall greenery. After several decades of growth, the trees are as tall as buildings or taller than them. Tall greenery is also present along the streets. Due to the low motorization index at the time of designing the architectural complexes in question, only a minimum number of parking spaces have been secured. Cars park along the streets, their entry into the interior of housing complexes is possible only to a limited extent.

\subsection{Living Comfort}

The issue of living comfort should be considered on two levels: architectural and urban. The assessment of comfort in the first of these aspects covers the functionality of apartments and buildings, and in the second covers the comfort of living resulting from the location in the urban structure of the city and access to services. As for the standard of flats and buildings themselves, the authors' assessment is critical. The flats are small in size, and the dimensions of the rooms are also unsatisfactory, especially corridors and bathrooms. The widths of internal doors as well as entrance doors to apartments do not meet the requirements currently imposed on newly erected buildings, i.e., they do not allow the use of flats by disabled people. The same is true of the limited widths of the stair flights, which make it difficult for people with mobility impairments, as well as for, e.g., bringing furniture or prams. This situation is worsened by the lack of elevators in most buildings.

The assessment of the living comfort from the point of view of access to urban services is fundamentally different. The considered housing complexes are currently located almost in the centers of the cities, which in the period following the completion of these complexes have significantly expanded. Such a location makes it possible to reach the city center on foot, or by means of well-developed public transport, especially since the distances to the nearest stop are short due to the density of the urban fabric. The existing infrastructure, usually implemented simultaneously with residential buildings, provides access to education, medical, trade, catering, etc.

Due to the fact that the nearby streets usually do not act as transit corridors, buildings are far from the road, and the space between them and the road is mostly covered with tall greenery, they are characterized by relative acoustic comfort. Due to the age of the buildings, the greenery, especially trees, is fully expanded, which results in ecological comfort. The insufficient number of parking spaces is a problem for those residents who prefer their own car as the primary means of transport in the city. 
Due to the passage of time, the habitation of people who are the original tenants of the apartments is sporadic. These are very elderly people. It happens that the current tenants are descendants in the first or second generation. In general, however, they had already met their housing needs before acquiring the flats in question by inheritance. Relatively young people constitute the largest group of inhabitants. Some of them are tenants of flats owned by the heirs of the original residents, while others have acquired from them the flats to own. The unequal dates of settlement of individual dwellings and the different attitude to their ownership are unfavorable to forming integrated micro-communities.

\subsection{Aims and Directions of Adaptation to a Contemporary Sustainable Living Environment}

The authors assume that the modernization of buildings and their vicinity would take place in the conditions of the displacement of residents, at least for the duration of the adaptation works. The first objective is the transformation of buildings with the aim of increasing the areas of apartments and facilitating access to them by equipping with elevators the buildings that do not have them. The extension of flats may be realized at the cost of reducing their number, e.g., as a result of the liquidation of one or two of the existing three or four flats accessible from the same landing and leaving only two separate flats. Such a change does not have to be made uniformly throughout the building. Greater diversification of the flats will mean greater social differentiation of the inhabitants. Technical difficulties may be an obstacle, especially in architecturally complicated parts of buildings. Supplementing buildings with elevators can theoretically most easily be achieved by adding external elevators. In general, staircases adjoin the external walls with parts including inter-story landings. Therefore, internal lifts must also be taken into account. Their incorporation into the existing structure of the building is definitely more difficult.

The second main goal of the adaptation proposed by the authors is to make spatially wider transformations within housing complexes and to supplement them with functions that would naturally favor the formation of a social bond integrating the inhabitants. In this context, internal courtyards and roofs should be considered as places for shared recreational spaces or the location of services that meet the living needs of residents. The latter aspect offers some residents a chance to work in the immediate vicinity of their place of residence. It is also possible to consider the use of premises located on the ground floors or basements of buildings as places for non-burdensome economic activities organized by residents themselves, provided for recipients from a wider circle than the neighborhood community. In this case, adequate access to these premises should be provided to outsiders. Pedestrian paths connecting entrances to residential buildings and service premises should be arranged in such a way as to facilitate accidental contacts between residents and encourage the use of services in the vicinity, in order to create as many opportunities for spontaneous acquaintance-making as possible.

The internal courtyards are an excellent space for the location of underground car parks, which could even be connected directly to the ground floor of the buildings by referring to the system of underground exits from the air ride shelters. The trees growing in the courtyards, which, due to their age and size, are one of the advantages of the considered residential complexes, are an obstacle for this solution. The concern regarding the presence of greenery can be realized in the design of gardens on flat roofs, including crops bearing the characteristics of urban agriculture, carried out under the open sky, as well as in greenhouses.

\section{Case Study-Residential Complex between Hetmańska and Staszica Streets in Rzeszów}

\subsection{Characteristics of the Housing Complex}

The in-depth analysis, aimed at implementing the concept outlined so far, was carried out for the housing complex in Rzeszów, including buildings at 28, 30, 32 and 34 Hetmańska Street, as well as 25, 27, 29 and 29a Staszica Street. All buildings are four-story, covered with flat roofs and situated along the boundaries of an approximately rectangular area 
measuring $240 \mathrm{~m} \times 60 \mathrm{~m}$. The space of the inner courtyard is developed mainly for recreational functions. Due to the discontinuity of the buildings and the presence of three gates, this space is accessible from the outside, and also for people other than the residents of the complex. The configuration of the buildings creates two main pedestrian paths. In two points, the entry of vehicles is allowed, for which a small number of parking spaces is prepared, as well as six single-car garages (Figure 2). The distance of the building complex from Hetmańska Street is approximately $20 \mathrm{~m}$. A row of trees, which are higher than the buildings, grow in this area. The distance between the buildings and Staszica Street is from a few to several meters. The area along Staszica Street is also wooded, and a few trees also grow within the inner courtyard (Figure 2).

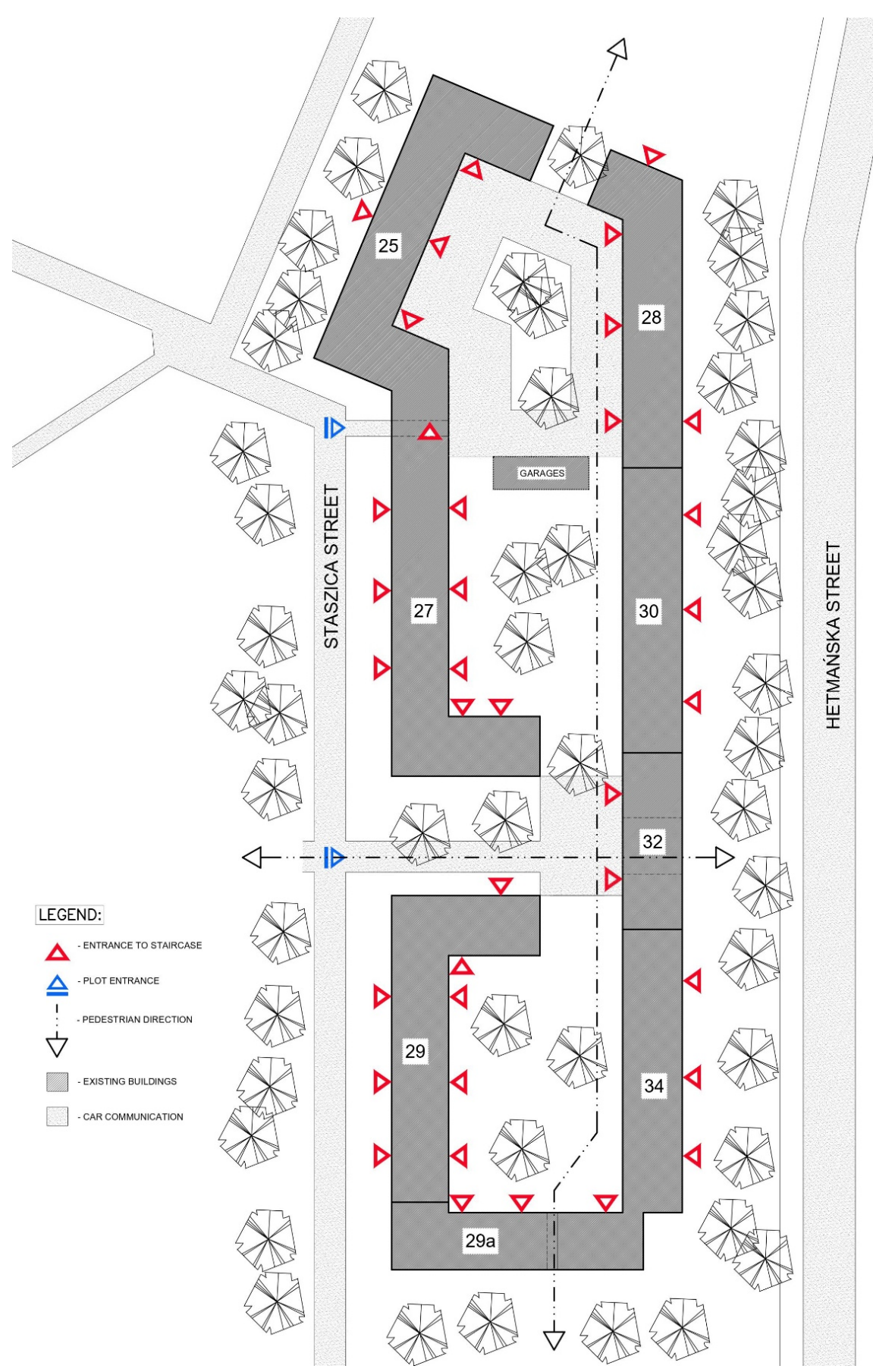

Figure 2. Residential complex at Hetmańska and Staszica streets in Rzeszów-situational plan. 
The residential complex was built in the years 1951-1955. Despite the shortness of this timeframe, it was not the result of a single design. The Hetmańska 30 and 34 buildings were erected the earliest as the result of the implementation of an urban plan providing for a loose structure of multi-apartment buildings in this area. Despite the fact that in the available documents, both the designs and the realization of the remaining buildings date back to 1955, the development concept was changed anyway during the implementation of the investment. The result of the overestimation is, inter alia, a lack of uniformity in the arrangement of entrances to buildings. Access to the Hetmańska 30 and 34 buildings is provided only from the outside of the housing complex, some of the staircases in the Hetmańska 28 and Staszica 25, 27 and 29 buildings have two-sided access, and the remaining staircases in these buildings and the staircases in the Staszica 29a building are one-way access, mostly from the inner courtyard (Figure 2). The Hetmańska 32 building stands out in the entire complex, possessing a monumental form, with the presence of commercial and service premises, and also as the only one under conservation protection in the form of an entry into the municipal register of monuments [61].

The changes in the concept of land development resulted from the premises described earlier. The scale of housing needs and the shortage of funds meant that also the original design of the architectural form was not completed. The elevations were made only a dozen or so years after the buildings had been inhabited. The final forms (Figure 3a) are therefore greatly simplified in relation to the designed ones, which were characterized by rich ornamentation (Figure 3b). This happened due to, among other things, the change in architectural canons that took place in the meantime, including the departure from socialist realist monumentalism.

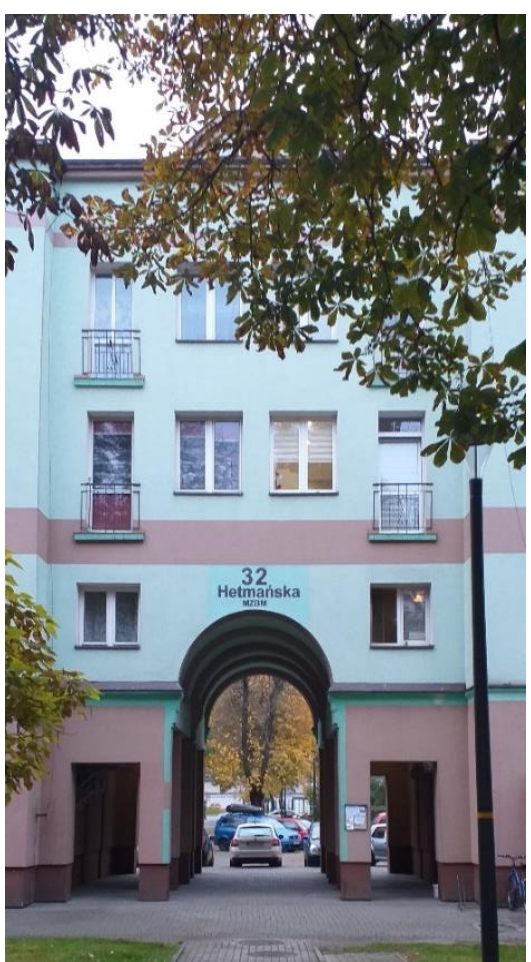

(a)

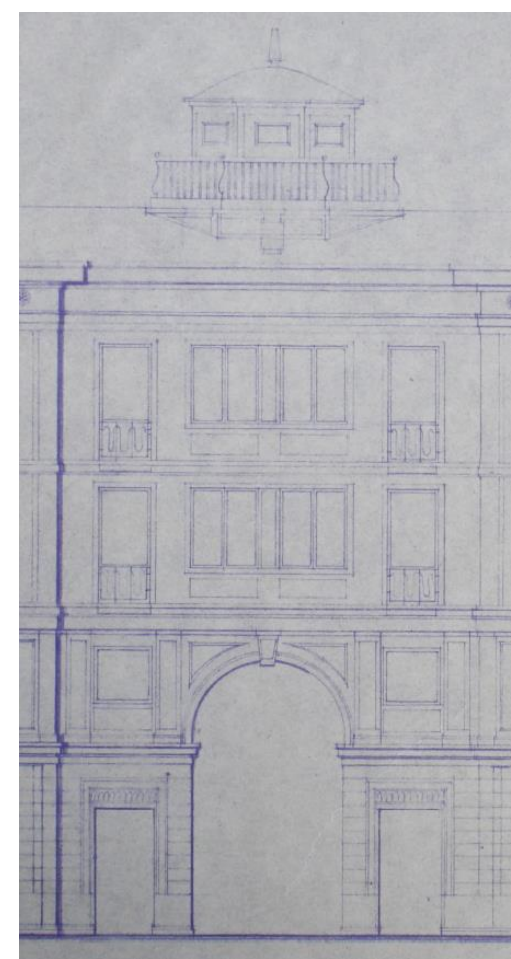

(b)

Figure 3. The architectural form of the Hetmańska 32: building: (a) existing condition, (b) design.

The state archival resources include complete designs for the buildings of Hetmańska 28 [62] and 32 [63] and Staszica 29 [64]. Apart from them, the authors had an insight into the installation designs for the buildings at Hetmańska 34 and Staszica 25, owned by the building administrator. The buildings of Hetmańska 30 and 34 are identical, and the buildings of Staszica 27 and 29 are almost identical, based on the same design concept. 
Therefore, it can be concluded that the knowledge of the authors about the entire housing complex, in terms of the functional layouts and structures, is sufficient to generally define the concept of their modernization in order to adapt to contemporary housing standards.

The buildings feature both repetitive layouts of apartments accessible from one staircase, as well as atypical layouts, mainly related to corner staircases. Due to the scientific and not design nature of this study, attention is focused on two typical systems with the highest repeatability. One of them is the layout of four apartments available from the same landing, in the Hetmańska 30 and 34 buildings (Figure 4). In this arrangement, the two apartments on the side of the street are two-room apartments, while two more, located on the backyard side, have three rooms. Stairways are situated on the street side and have only one entrance. The layout of the apartments in the Staszica 27 and 29 buildings is different. On repeatable floors, there are three three-room apartments accessible from one landing (Figure 5a). As staircases in these buildings have entrances on both sides of the building, there are only two apartments on the ground floor, each with four rooms (Figure 5b).

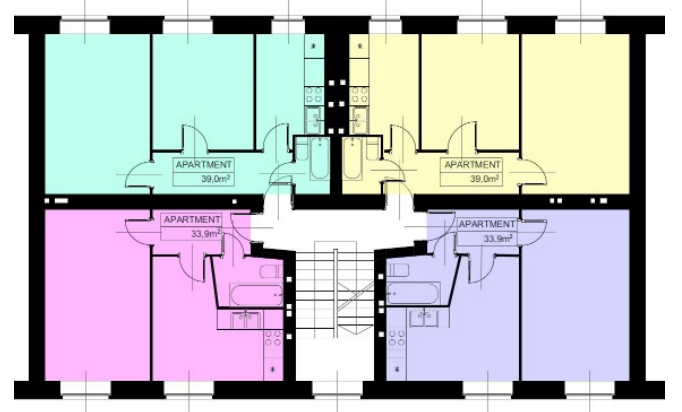

Figure 4. The existing layout of apartments in the Hetmańska 30 and 34 building.

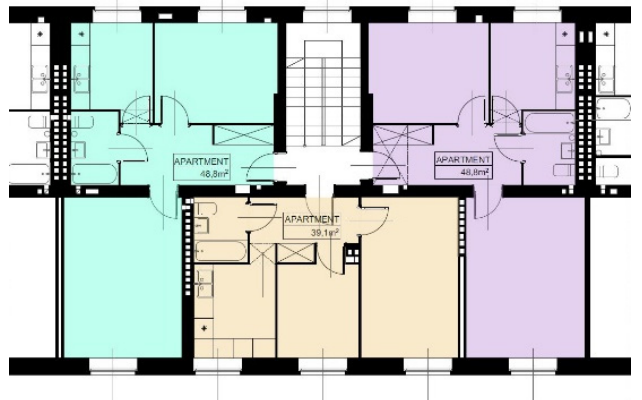

(a)

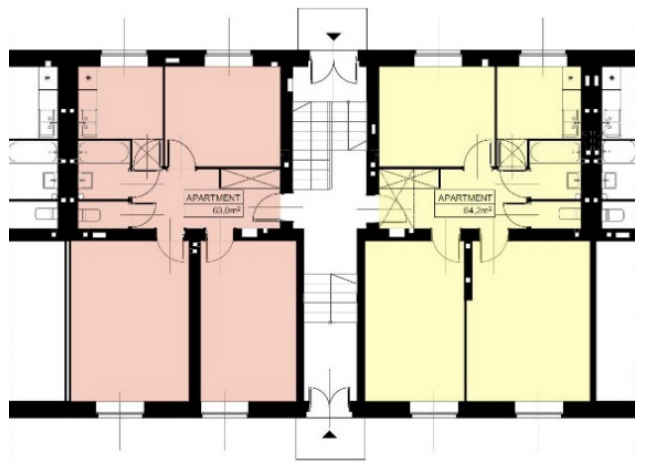

(b)

Figure 5. The existing layout of apartments in the Staszica 27 and 29 buildings: (a) repeatable story, (b) ground story.

The construction walls of all buildings are made of brick, mainly solid brick, with the exception of the outer walls of the second and third floors, which are made of perforated bricks. The thickness of the walls of the basement and the ground floor is two bricks, and that of the walls of the first, second and third floors is 1.5 bricks. The floor slabs are DMS-type multi-ribbed structures with beam spacing of $650 \mathrm{~mm}$. The layout of the structural walls is longitudinal; however, in the Staszica 27 and 29 buildings, the large number of openings in the internal structural wall means that in fact, in terms of static work, they constitute a series of pillars. Internal walls are made of brick or aerated concrete. Inter-apartment walls attract attention. They are designed as two separate thin walls with a void between them. The excess number of chimneys is another characteristic feature. 
This is a consequence of equipping all rooms with gravity ventilation and the kitchen with smoke ducts. The floor slabs are devoid of an acoustic insulation layer. The parameters described above characterize the Staszica 29 building exactly. It should be assumed that the buildings for which the documentation was not preserved are the same, because all (except for the Hetmańska 30 and 34 buildings) were designed in the same design studio in the same year.

\subsection{General Assumptions of the Proposed Changes}

The compactness of the development, the flat roofs allowing for the diversified use, the parameters of the building structure enabling the introduction of additional loads resulting from the development of the roofs, as well as the greenery in the surroundings, including trees growing above the roofs, have been considered by the authors as the strengths on which the modernization concept was based. The proposed changes of an architectural and construction nature concern the improvement of the standard of flats and supplementing the housing complex with functions that would favor the natural formation of social relations between the residents. The authors set out for themselves the goal of combining the identity of the housing complex, expressed by its established architectural form, with elements that give it the attributes of modernity. In this spirit, they focused on finding solutions in which the cubature of complementary building elements would be visible to a greater extent from the side of the inner courtyard, and only minimally from the outside. The permanence of a generally accessible architectural landscape would thus be able to balance with the modern image of the surroundings viewed from inside the apartments. The authors were guided by the idea that the scope of changes should not be limited only to those that make the housing conditions in this several dozen-year-old housing complex similar to the conditions offered by modern construction, but also those that create a housing environment that fits in with future trends.

\subsection{Changes Improving the Standard of Flats}

The intention of the proposed changes is to increase the comfort of living and increase the average flat area in order to create more conditions for attracting, among others, wealthier and developmental families. Equipping buildings with elevators and apartments with balconies, as well as increasing the acoustic insulation of floor slabs and walls between the apartments, are the changes that significantly improve the living comfort. Increasing the average floor space of a flat requires the liquidation of some of them and the enlargement of the remaining flats by the area obtained from the liquidated ones.

The methods of equipping existing buildings with passenger lifts that are easiest to implement is the installation of internal lifts in the empty space between the flights of stairs or the addition of external lifts. The first option is not available in any building within the complex. The second solution, with the simplest approach to the problem, would provide only half of the benefits. Due to the fact that, with one exception, the staircases are positioned with inter-story landings adjacent to the outer wall, the arrangement of elevator access points on these landings would mean that a level difference equal to half a story would have to be overcome by stairs. Despite this inconvenience, such solutions have been used in practice [65]. The authors, not content with the possibility of a partial success, looked for fully functional solutions. The technical possibility of equipping staircases with access to lifts was therefore considered together with the issue of transforming the layout of flats on the story.

Two fundamentally different solutions have been proposed. A solution consisting of the incorporation of an elevator shaft inside the building has been presented for typical Staszica 27 and 29 buildings (Figure 6). Access to the elevator would be provided from the levels of individual floors through the widened existing door openings leading to the apartments undergoing liquidation. In this way, the structure of the load-bearing walls would not be substantially disturbed, but the structure of floor slabs would have to be destroyed. The transverse arrangement of the floor beams favors this possibility. It would 
be required to demolish the strips of floor slabs and supplement them with new pairs of beams along with the slabs supported on them, supplementing the floor slabs in places behind the elevator shaft.

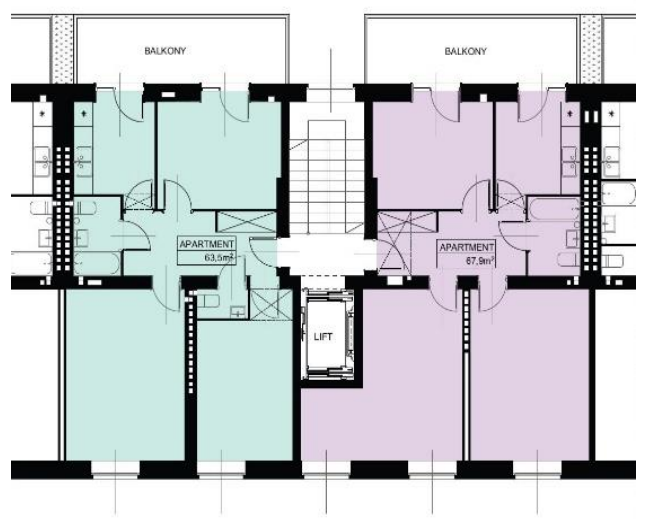

(a)

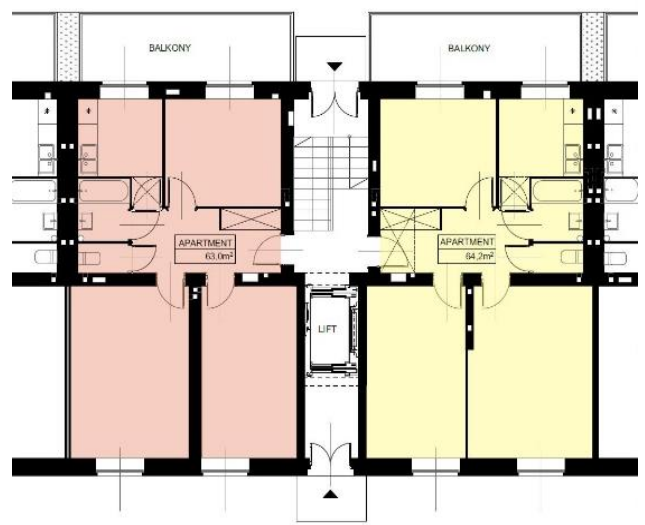

(b)

Figure 6. Functional layouts of the Staszica 27 and 29 buildings after modernization: (a) repeatable story, (b) ground floor.

As for the access to the staircase from the outside of the building, the entrance from the street would provide access to the elevator, and the entrance from the courtyard would provide to the stairs. The elevator shaft would have to be equipped with a cabin with two doors situated on opposite sides. The concept of internal elevators in these buildings is largely conditioned by the intention of limited interference with the external appearance of the buildings from the street side, which excludes the addition of external elevators from this side. The addition of external elevators from the courtyard side is incompatible with the intention of providing access to the elevator from the story levels and not from inter-story landings.

The external elevators are proposed for the Hetmańska 30 and 34 buildings. The reverse location of staircases in these buildings, i.e., from the street side, allows for the addition of external elevators from the courtyard side, in accordance with the arguments presented earlier. Access to elevators requires that a part of the area used previously as residential has to be allocated to communication, as well as some windows have to be eliminated (Figure 7). Each of these changes, considered separately, should raise objections. However, the authors believe that their legitimacy cannot be considered in the context of individual losses, but the benefits of the overall proposed changes.

From the point of view of the architectural form, external elevators would be a perfect complement to the added balconies. For balconies and elevators, a common structure can be used, completely independent of the structure of the existing building, and it can also be used for the arrangement of photovoltaic panels (Figure 8). Even the offer of ready-made technical solutions of this type is known [66]. The additional entrances related to the addition of elevators to buildings, which have so far been deprived of access from the courtyard side, is important for shaping social relations between the inhabitants of buildings located on the opposite sides of the courtyard. Alternatively, the use of internal elevators and making entrances to the staircases from the courtyard side may be considered. However, it is not preferred, as the solution interferes more with the current structure of the building and is possible to avoid. 


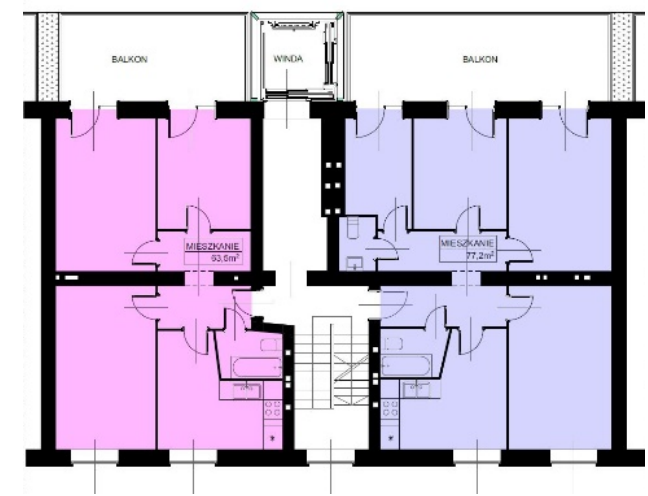

(a)

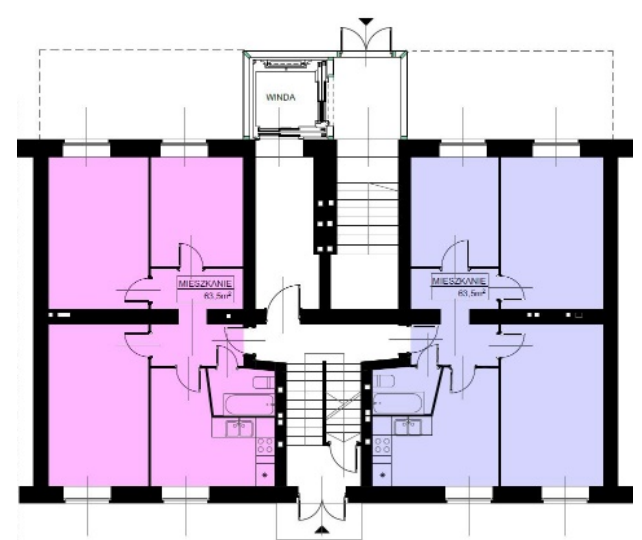

(b)

Figure 7. Functional layouts of the Hetmańska 30 and 34 buildings after modernization: (a) repeatable story, (b) ground floor.

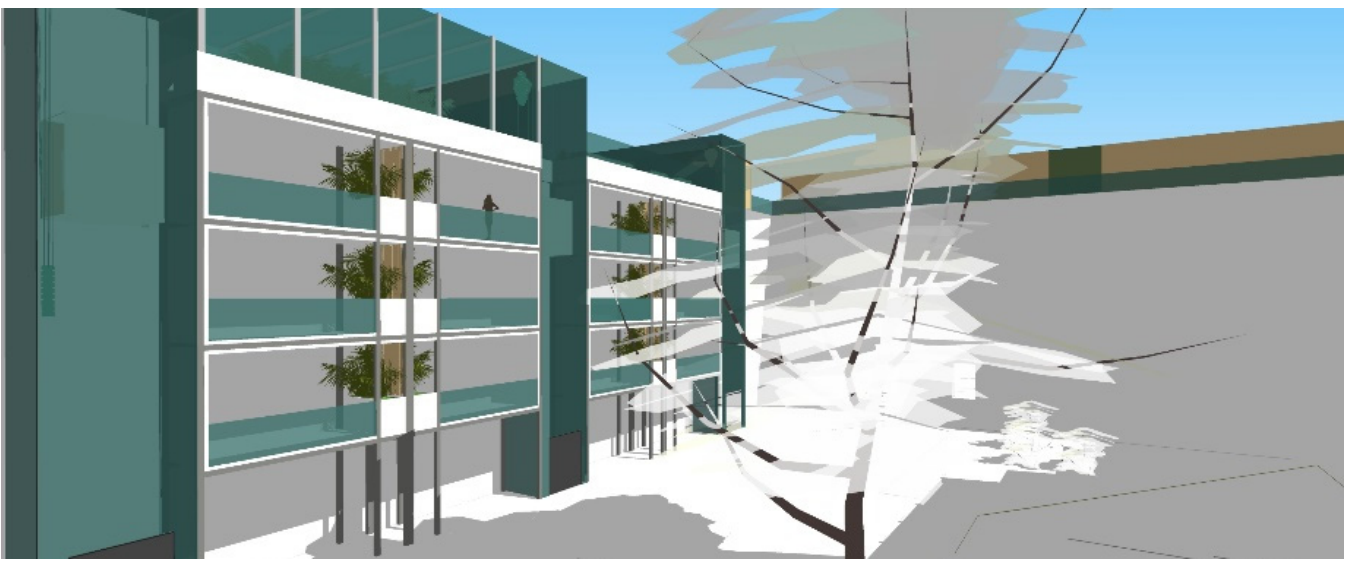

Figure 8. View from the courtyard of the Hetmańska 30 and 34 buildings after modernization.

The changes to the functional layout of the stories and the location of the elevators are explained together in the same figures. As a result of the transformations, two apartments on one floor will be available in the Hetmańska 30 and 34 buildings in place of the previous four. On the ground floor, each apartment will have four rooms, and its area will be $63.5 \mathrm{~m}^{2}$. The size of the apartments on the left and right side of the staircase on repeatable floors will differ. The creation of one larger apartment on the right side of the staircase (Figure 7a) is based on the simple connection of two existing apartments, and so it is also possible to consider keeping the existing layout. However, this means that an apartment facing the street would still be an apartment without a balcony.

In the Staszica 27 and 29 buildings, the transformations of the apartments cover only the first, second and third floors. Two apartments, each with four rooms, with areas of 63.5 and $67.9 \mathrm{~m}^{2}$ are planned in the place of the three existing ones. A positive of the proposed modernization is the change to the functions of some double walls (Figure 5a) from inter-apartment walls to indoor ones (Figure 6a), which will eliminate the discomfort resulting from the acoustics of this wall. The function of an inter-apartment barrier will be taken over by a new wall, made according to the standards of acoustic comfort. Unfortunately, some walls built in the same way will retain their current function. In order to increase their acoustic insulation, it is possible to fill the internal space with PUR foam, which requires making in the wall a limited number of holes with a diameter of several millimeters [67]. The improvement of the acoustic insulation of the floor slabs can be achieved by sticking a layer of insulation material onto the ceiling surfaces. Supplementing 
the floors is not possible, while lowering the room height due to adding a cladding will not bring negative consequences due to the significant height of the rooms, currently $2.75 \mathrm{~m}$.

The presented solutions for elevators can also be used in other parts of the complex. The unusual spatial situation related to staircases in the corners of buildings requires additional conceptual work. In the case of one staircase (in the Hetmańska 28 building), the addition of an external elevator that will meet the postulates of location on the courtyard side and access directly from the story levels will be possible without the need to interfere with the existing layout of the rooms (Figure 9). In several other places, the possibility of eliminating separate flats in corner staircases can be considered in favor of attaching them to flats accessible from adjacent staircases. In this way, a certain number of especially large apartments would be arranged in a housing complex. Alternatively, the present flats accessible from the corner staircases could constitute separate parts of these enlarged apartments, intended for office work. Access for clients would be provided from the corner staircase, while the residents would use the adjacent staircase equipped with an elevator. Deciding not to equip the corner staircases with elevators ensures greater freedom in arranging the roof surface, which can be perceived as an additional benefit.

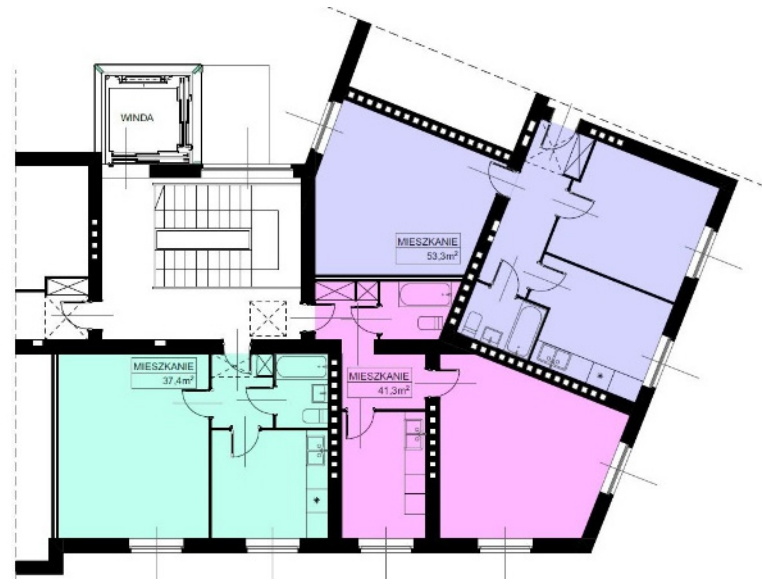

Figure 9. Extension of the Hetmańska 28 building with an external elevator without interfering with the existing functional layout.

\subsection{Roof Development Concept}

Economically, the most appropriate way to develop roofs is to add additional apartments [68]. As the funds obtained from selling them at market prices are higher than the construction costs, the financial surplus is able to partially compensate for the expenses incurred for the modernization of the entire building $[69,70]$. The authors concluded that the features of this particular set of roofs support the introduction of functions conducive to the creation and maintenance of social bonds as the basic means of roof development. To some extent, the current development of the inner courtyard is dedicated to such purposes, thanks to equipping it with play devices for children, a gym for adults and benches. The drawbacks that can potentially discourage at least some residents from using these devices are the exposure to the views of the apartments surrounding the courtyard and access by bystanders or animals. The objective defect is the lack of protection against atmospheric influences.

Objects and devices on roofs are deprived of the above-mentioned inconveniences. As access to the roof surface will be from staircases, the offered activities can only be undertaken by residents and watched only by those interested in using the infrastructure available on the roof. The access to staircases from the roof will be secured in the same way as access to them from the ground level. In this way, the access to individual staircases from the roof level will also only be for people living in apartments serviced by them.

In the presented concept (Figure 10), the roof is partly covered with roofed objects, and partly with an open space, dedicated mainly to collective gardening. Some of the covered 
spaces are greenhouses, designed as places where the passions of the interested residents can be upheld during the part of the year preventing the cultivation of open crops, and thus the social relations established between them will be able to be maintained. Glass, as an external cladding, serves also to formally diversify the roof buildings. The remaining closed rooms of the roof development are designed as multi-functional spaces. They can be used depending on the preferences of residents, and there is the possibility of equipping them as a year-round gym, a table tennis room, a place for culinary experiments, a club for board games, etc. It is expected that both the structure and external cladding of these objects will be made of wood or wood-based materials.

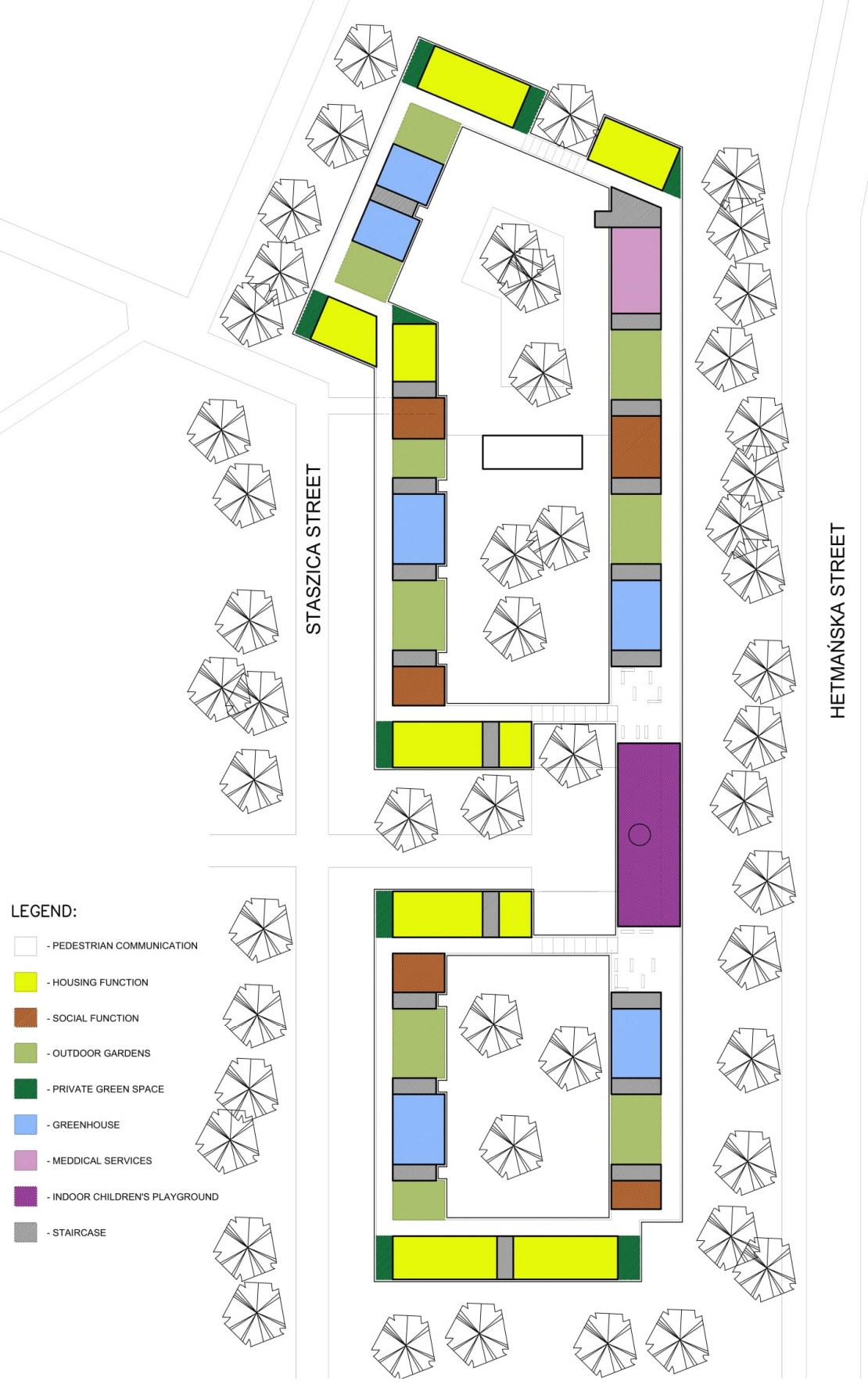

Figure 10. Concept for the development of roofs over a complex of buildings. 
It is especially desirable that one of the available functions is babysitting, which is needed in the afternoon and evening hours and on days off from work, when educational and care institutions are closed and parents occasionally need to leave the house without their children. If strong social ties are created between the residents, childcare will be able to be provided in a specially designed room, on the basis of neighborly self-help. The optimal place for the function of the playroom for children is the roof of the Hetmańska 32 building (Figure 10), due to the central location of this building in the complex and the presence of a turret, which may be an additional attraction, especially if the viewing platform situated within it could be supplemented with a slide (Figure 11).

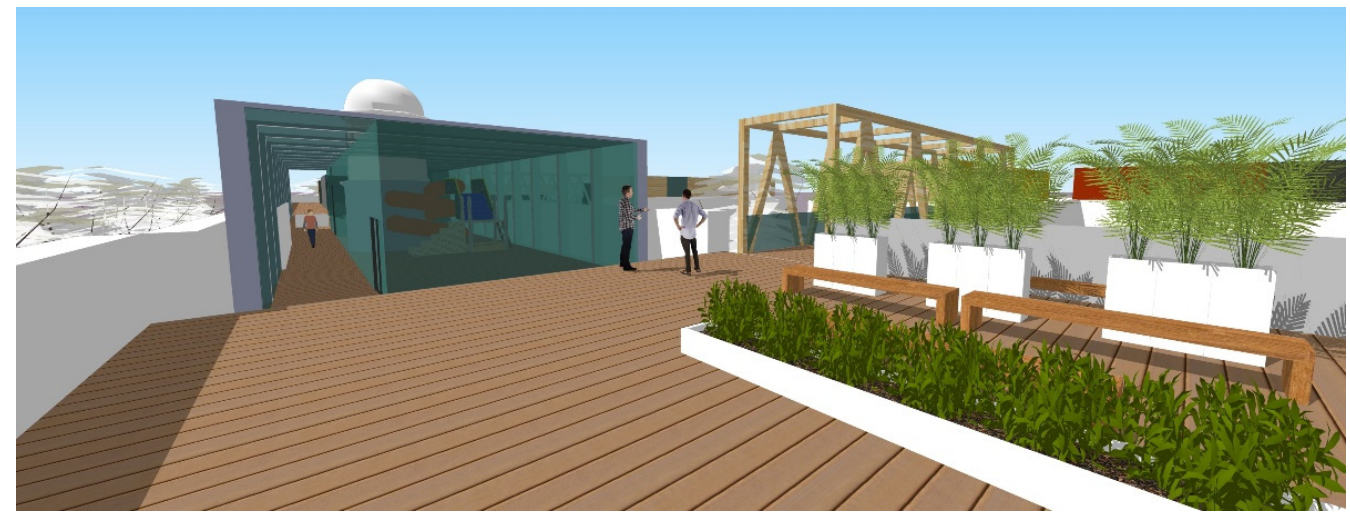

Figure 11. A playroom for children with a slide using the existing turret.

An all-round path is planned on the roof in order to provide equal access to all offered functions to the residents of all staircases in the entire housing complex. The location of the path on the outer sides of the buildings, especially in the parts located along the streets, forces the buildings on the roof to be withdrawn inwards (Figure 10), and thus minimizes the change in the appearance of the complex perceived by street passers-by. The path should, in addition to the function of a necessary communication route, also contribute to strengthening social ties. From this point of view, it is important that the length of the road to individual points does not discourage an individual from traversing it, and that an even flow of pedestrians in the vicinity of each of the offered functions is ensured. An objective circumstance persuading residents to wander the roof is the fact that they will have access to it only from their own staircases. The use of glazing in the walls adjacent to the path and the installation of benches would be another incentive for creating a community.

The attractiveness of the benches located on the roof would be completely different than that of the benches in the inner courtyard. They would offer a vast vista of views without losing contact with the greenery, which is accessible in this space in the form of the crowns of trees rising above the roof (Figure 12). The connection of the roofs of Hetmańska 28 and Staszica 25, Hetmańska 30 and Staszica 27 as well as Hetmańska 34 and Staszica 29 by means of three footbridges (Figure 10) is proposed to maximize the success of the roof in fulfilling its social role. Connecting the roofs of nearby buildings with footbridges is a solution that has been used in practice [70]. The arrangement of footbridges gives the path the shape of two closed loops, with the playroom situated between them, which is the central place for the roof development. This corresponds to the dominant importance of the Hetmańska 32 building in the composition of the entire housing complex. We propose constructing the footbridges out of wooden truss girders (Figure 13). 

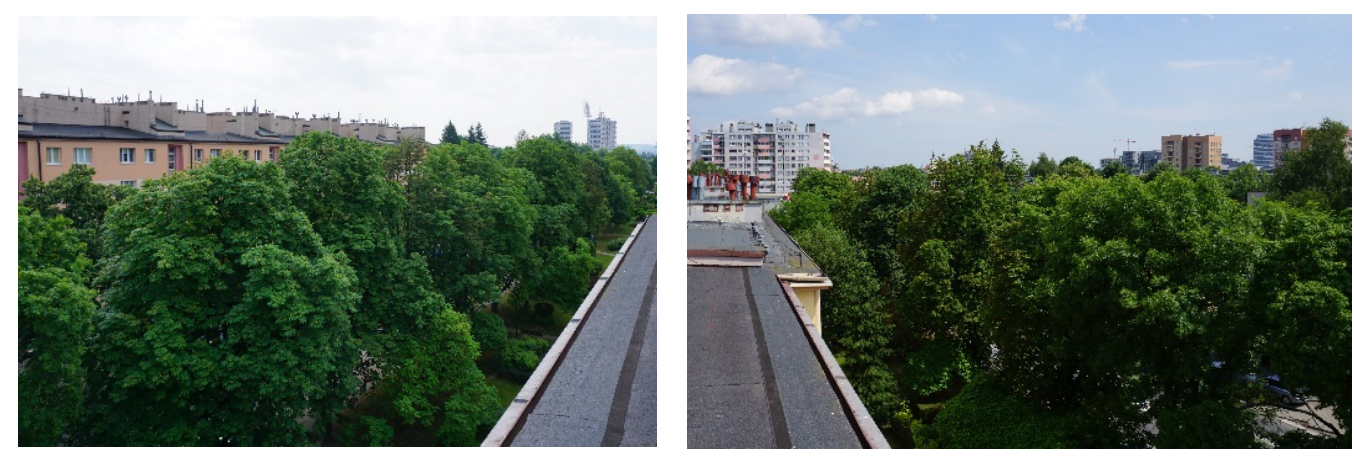

Figure 12. Tree crowns rising above the roof.

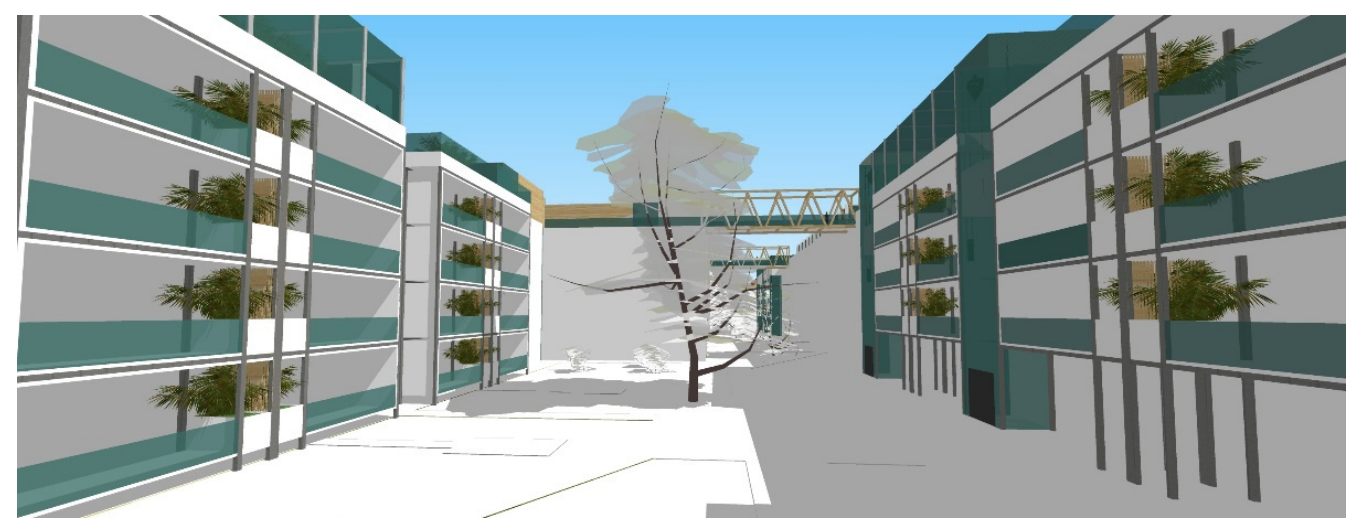

Figure 13. Pedestrian bridges connecting the roofs.

The walking path mainly follows the outer, but partly also the inner edges of the roof (Figure 10). Thanks to this, walking along it creates an opportunity to observe both the external surroundings of the complex from all sides, as well as providing insight into the space of the inner courtyard. Combined with the close presence of tree crowns, the absence of buildings obscuring the panorama of the area and less street noise, it has the potential to be a more attractive place for walks than pavements on the ground. The recreational functions offered on the rooftop and in the inner courtyard would complement each other. In the courtyard, activities that are not available on the roof could be undertaken, e.g., walking the dog, playing in the sandbox, riding bikes, etc. There, contact with people from outside the community of the housing complex could take place. The roof offers greater privacy, security, and exclusivity.

Basic medical care, i.e., a family doctor's office with a treatment room and a physiotherapy room, is another function desirable in a residential complex that could be located on the roof. The rooms for this purpose must, however, be designed differently from the other previously discussed rooms. It is impossible for a doctor or physiotherapist to be able to make a living only from services provided to a group of patients as small as the population of the considered housing complex. Their offices should be accessible not only from the path, but also via an elevator directly from the ground level (Figure 10). The developed concept includes an external elevator that provides direct access to the rooms where medical services are provided.

As mentioned at the beginning of Section 5.4, the introduction of additional living space provides measurable economic benefits. The large area of all roofs in the complex of buildings in question makes it possible to find places for residential purposes. An argument supporting such a solution is the possibility of designing flats on the roof larger than flats on lower floors. Greater diversification of the range of flats in terms of their area and functional layouts is in line with the concept of sustainable social development, as it makes it more likely that the complex will be inhabited by residents of various ages and material statuses. 
The all-round path is a certain obstacle for introducing flats, and large ones at that, to the roof surface. Apartments with windows located in only one of the walls are the least attractive [33]. The possibility of introducing windows from the path side should be ruled out. Alternatively, small windows, placed high, which can be used to illuminate sanitary or auxiliary rooms, could be considered. In the presented concept, the residential function was introduced mainly in the corner sections of the roof (Figure 10). In corner apartments, windows can be arranged in two perpendicular walls. The use of the roof area for a residential function can be achieved by arranging single-story apartments with entrances on the fourth floor, or by converting apartments on the third floor into two-story apartments.

\subsection{Premises Intended for Commercial Activities}

The presence in a housing complex of rooms that could be rented by some residents in order to conduct light work is considered an important feature of a sustainable housing environment [33]. So far, only the possibilities of providing medical services have been indicated, but more because of the demand for such services from the community of residents than in the context of work on the spot by some of them. The arrangement on the roof of rooms for doing work requiring contact with external customers would necessitate the same organization of access as medical offices, and therefore it is not taken into account.

Section 5.3 mentions the possible location of office work premises accessible from corner staircases, but the problem of external access will be reduced if it is provided directly from the ground level. There are two commercial and service premises in the Hetmańska 32 building, which can be considered as the workplace of the residents. Currently, both are occupied by a confectionery shop; one of the premises has a consumption room, and the other one is a baking studio. It is essential to find locations for other such rooms. According to the authors, some specific works may be carried out in rooms located in the basement of the Hetmańska 30 and 34 buildings. The parts of these basements located on the side of the courtyard are currently divided into storage rooms for individual apartments (Figure 14a). If the number of flats in these buildings were to be reduced, storage rooms of the same number as at present would turn out to be redundant. For eight apartments in the staircase, a sufficient number of storage rooms can be arranged in the section of the basement floor facing the street (Figure 14b).

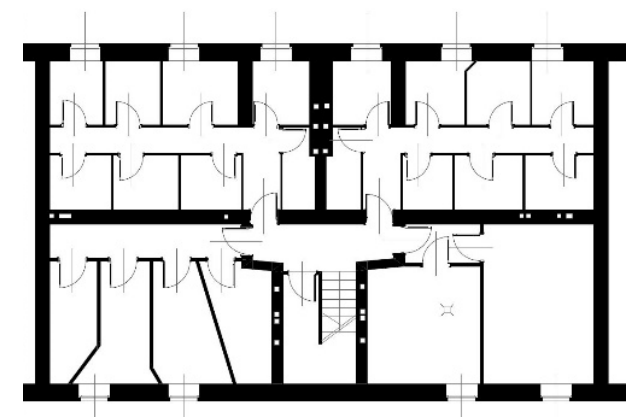

(a)

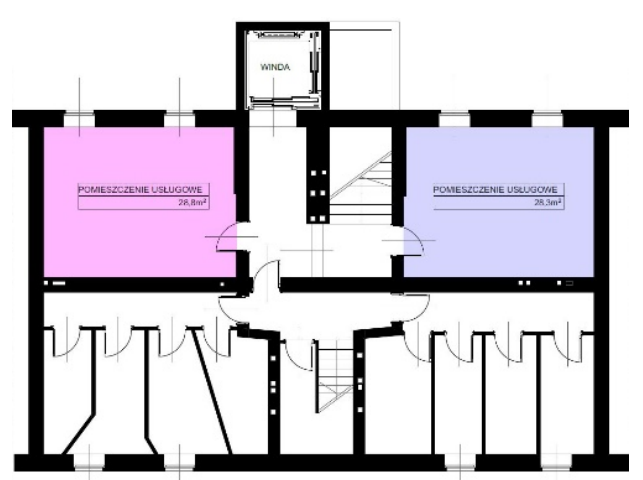

(b)

Figure 14. The functional layout of the basement of the Hetmańska 30 and 34 buildings: (a) current state, (b) the state after modernization.

The advantages of the rooms in the basement of the Hetmańska 30 and 34 buildings are relatively large windows and the possibility of easy access from the outside through the vestibules of external elevators (Figure 7b, Figure 14b). The disadvantage is the height of the rooms, less than $2.5 \mathrm{~m}$, which, according to the building regulations in force in Poland [71], is insufficient for rooms intended for work. However, other regulations [72] allow the use of such rooms for work not exceeding 4 hours a day. Since the presence of rooms such as that proposed is important, especially from the point of view of providing 
work opportunities in the vicinity of the place of residence for less mobile people, e.g., pensioners or people with disabilities who, due to their age or limitations, may be interested in working on a limited-time basis, the idea may be treated as rational. The premises could also be used for additional paid activities by persons employed elsewhere. An issue that cannot be ignored is the access of light into the rooms in the conditions of adding external balconies. In this case, in the apartments on the ground floor, there should be no balconies (Figure 8).

\subsection{Construction and Building Aspects}

The concept of the revitalization of the housing complex corresponds to the assumption that the modernization works will be carried out after the eviction of the residents of at least those buildings in which construction and assembly works are currently being carried out. Reducing the number and increasing the area of flats is a reason to consider that the analysis is the use of the existing building substance to create a new housing stock, and not the improvement of the quality of life of residents currently using these flats. The authors disregard the legal and economic issues that would enable the transformation of the housing complex in the conditions of the present ownership status, the attitude of current residents and the possibility of the success of this project in the current market conditions.

The key aim of the authors was the least possible interference with the material structure of buildings, especially with the structural elements. The intervention with the greatest scope is the incorporation of internal lift shafts (see Section 5.3). The necessary demolitions, despite the scope insignificant in relation to the cubature of the entire building, should be carefully planned, due to the fact that they relate to the space extending over the entire height of the building. It is suggested that the floor slabs should be demolished one at a time and the debris be removed from the building after each slab is demolished. The replacement structural elements should also be supplemented successively in order to avoid the loss of stability by the external wall.

The floor slab above the highest story is not prepared to accept additional loads. For that reason, an additional structure is assumed to be built, but in order to avoid demolition works, not at the site of the existing slab, but above it (Figure 15). The floor beams would rest on longitudinal structural walls whose material and dimensional parameters are able to cope with the additional load. The superstructures of several other buildings from the same period and built with the same technology, made in the vicinity, prove this. In order to reduce the thickness as much as possible, the floor slab could be made using slim floor technology [73], i.e., in such a way that the slab is placed not on but between the structural beams. In order to minimize the weight of the structure, the beams are recommended to be made of aluminum profiles.

Due to their low weight, aluminum and wood are the materials from which the structural elements of all superstructures should be made. The use of them as facing materials is also recommended. Glass, metal and wood will clearly distinguish themselves from the existing plaster facades. Thus, the new elements of buildings will be exposed against the background of parts that are remnants of their original forms.

The chimneys are a significant obstacle in the arrangement of the roof. Those that are not used can be removed. The removal of chimney pipes within the building's stories does not have to be connected with this. The ambition to transform the complex into a modern living environment requires that buildings be fitted with mechanical ventilation. In such a case, the ventilation ducts placed in the existing chimney channels could run above the roof rather than vertically upwards, especially since there would be an empty space between the highest of the existing floor slabs and the additional one. 


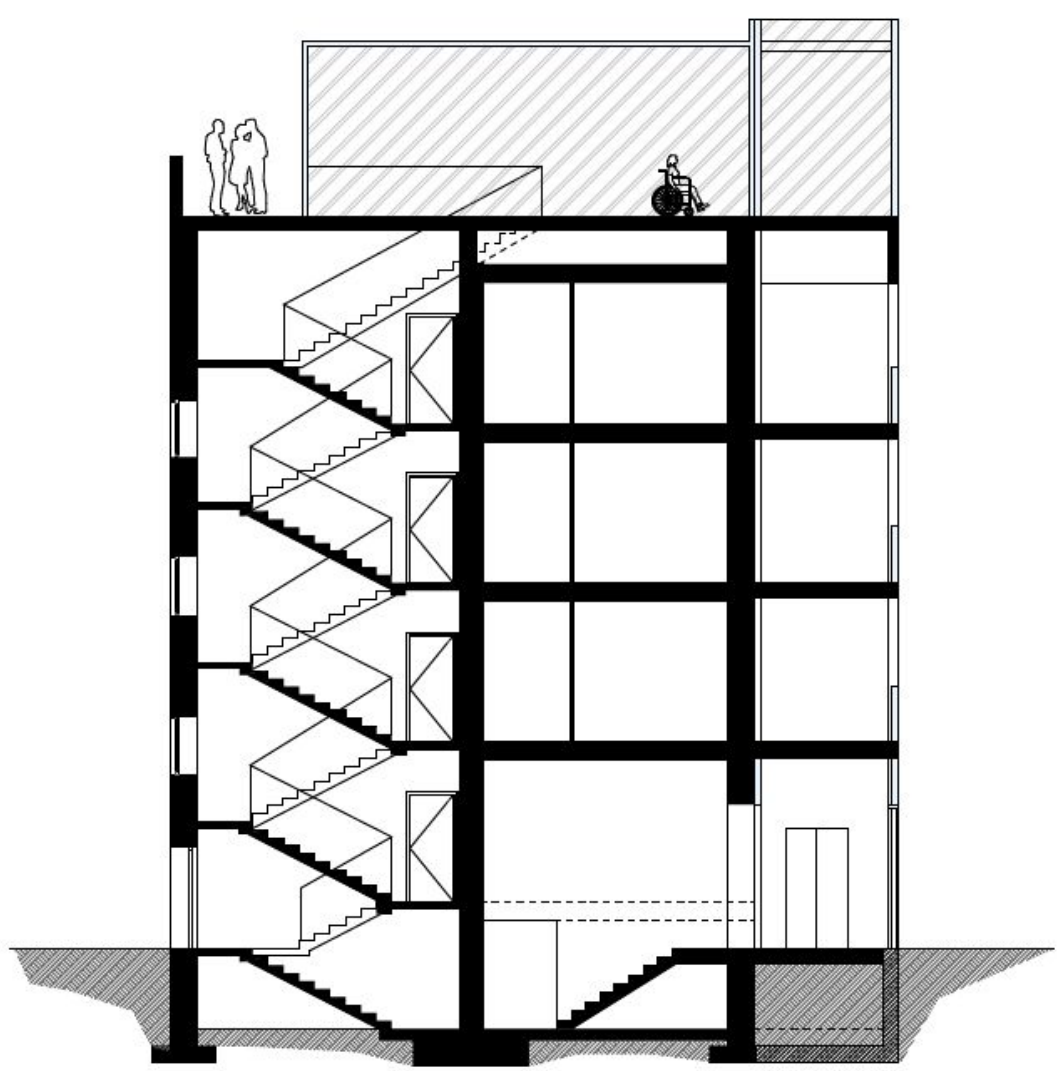

Figure 15. The cross-section of the Hetmańska 30 and 34 buildings after modernization.

\subsection{Ecological Aspects}

The transformation must be designed in such a way as to reduce the demand of the residential complex for energy and water supplied from the outside, as well as to contribute to the reduction in the levels pollutants in the atmosphere. The main factor generating benefits for the atmosphere is the location of the complex in the city center, where most destinations are easy to reach on foot or by public transport. It is therefore important that so many apartments as possible are inhabited by people of working age, including families with children. The mobility of such a group is the greatest, therefore from the reduction in the use of the residents' own cars may bring the greatest benefits to the city.

The introduction of vegetation to the outer surfaces of the buildings is the next factor increasing the positive impact on the quality of the atmosphere. In addition to the partial allocation of the roof area for garden crops, vertical gardens on the facades of buildings are also proposed. Pots with planted climbing plants can be arranged on the supporting structure of balconies. In this way, the additional load would not be transferred to the existing structure of the buildings, and the facade would not be subjected to the destructive influence of vegetation, as in the case of plants climbing directly up the wall. Residents would have contact with greenery at their fingertips, which they could cultivate on their own. The trellises supporting the vines in planes perpendicular to the walls would create green partitions between the balconies of neighboring apartments. They would ensure relative intimacy without taking the impression of lightness from the structure, unlike in the case of partitions made of durable material. The facades of the walls from the outside of the complex, the form of which remains unchanged, can be painted at least partially with photocatalytic paint [74], which uses the energy of light to reduce nitrogen oxide present in the atmosphere.

The authors intend to equip the modernized buildings with photovoltaic cells. Sufficient energy for meeting the common needs of residents, i.e., the service of lifts, lighting of staircases and common spaces on the roof, etc., should be sourced from photovoltaic cells. The cells can be placed on the roofs of the superstructures and vertically on the supporting 
structures of balconies. Transparent glass with photovoltaic properties should be used in greenhouses. The location of most buildings in the north-south direction is not conducive to the efficiency of panels arranged on planes parallel to this direction. Additionally, the relatively short distance between the buildings limits sunlight. The use of photovoltaic panels on vertical surfaces from the courtyard side is rational only at the levels of the top floors.

The last issue considered in terms of ecology is the management of rainwater. As in the case of energy obtained from photovoltaic cells, rainwater is not expected to be used to meet the individual needs of residents. The roof water yield would be so small in relation to the general needs of the residents that any reconstruction of the existing plumbing to use this water is irrational. Water can be used to irrigate crops in roof gardens and greenhouses as well as vertical gardens. It should be stored at heights that will allow gravity irrigation. The arrangement of small water tanks on the structure supporting vertical gardens is easy to imagine, because new structural elements can be designed with this load in mind. Water tanks on the roofs of buildings are more problematic. In order to avoid additional loading of the building walls, the location of the roof tanks can be considered also on the structure designed for external balconies and lifts.

\section{Discussion}

The development of flat roofs represents the most important element of the transformation of the residential complex in question. It strengthens the layer structure of the buildings, found as being better than the mono-functional option [75]. The development of the roof mean that not only the ground floor stands out from the other floors. The additional usable level obtained as a result of the roof development is qualitatively comparable to the level of the ground floor in terms of contact with the natural environment. In buildings with only a few stories, the proximity of each story to one of the two of these levels in practice equalizes the attractiveness of the apartments on all floors.

In addition to the benefits important for potential residents of revitalized housing complexes, the superstructure complied with the presented concept provides benefits on the scale of the entire city. It restores degraded quarters to their original value, or even increases it, because it is done neither by purely conservative conservation, nor by replacing the old architectural substance with a new one, but by combining contemporary elements and historical values. The unusual and original modernization of buildings is able to make the space around them more attractive, so that it will also attract residents of other districts.

The spatial conditions of the building complex which is the subject of the case study, on the one hand, allow for the consideration of concepts that are impossible to implement in residential complexes based on other configurations, on the other hand, they do not exhaust all the possibilities that could be implemented in some complexes. First of all, the location of so many functions on the roof and the spatial looping of paths, enabling the users to contact a large number of other users, will not be possible where buildings are not connected to each other in large complexes. Additionally, the connection of roofs with footbridges should be excluded when the distances between the buildings are greater, both due to costs and the destruction of the architectural composition.

The lack of high greenery within the courtyard, although unlikely, but not impossible due to the repetition of similar constructions in numerous locations throughout Poland, would be an argument in favor of building an underground car park in such a place. Parking under the courtyard, i.e., centrally located in relation to the apartments, would additionally strengthen the sense of security and community, and would organize the space of nearby streets. The possible presence of more retail and service premises is, in turn, an opportunity to attract more basic services and more jobs for local residents.

\section{Conclusions}

The concept presented in this article is a part of the discussion on the future of postsocialist architecture. The vast resources of it are found in cities not only in Poland, but 
also in other countries in Eastern Europe. As a result of the rapid development of Eastern European countries in the last 30 years, a large number of new apartments have appeared on the housing market. Older flats which have not been renovated or modernized have lost their attractiveness.

The problem of increasing the attractiveness of living in housing erected before the end of the 1980s is an issue that engages many researchers. Most of the studies, however, concern newer constructions, implemented after abandoning the doctrine of socialist realism and erected with industrialized methods in the so-called large-panel technology $[25,27,76,77]$. In this case, revitalization projects concern the space around the buildings more often than the buildings themselves, because the scope of possible interference with the structures of these buildings is minimal. Moreover, in large-panel buildings, due to the fact that they are newer, a considerable number of flats are still inhabited by inhabitants of the first settlement, which complicates the issue of a possible far-reaching modernization, due to the strong identification with the place of residence in its current form. The social problems in newer buildings are not as severe problems as in older ones [26].

The problem of revitalizing buildings erected using traditional technology is raised more often in Western countries, where large-panel construction was not used at all. A good example that may be a reference for the case study described in this article is a project to revitalize a housing estate in Milan, realized in the form of a didactic experience [78]. Factors differentiating traditional and large-slab technology mean that although the problems to be solved in both types of housing are similar, the methods of transformation must be different.

The architecture of the socialist realist period is a gap in terms of being filled with visions of far-reaching transformation. The relatively distant time of its creation makes one think about a certain protection of values perceived in such a time perspective as historical. On the other hand, the standard and technical conditions of apartments do not disqualify these buildings as much as, for example, buildings from the turn of the 19th and 20th centuries. In relation to the latter ones, deep modernization works are undertaken on a large scale, regardless of their historical origin. Modernization consisting of the reconstruction of the structure of the rooms and the expansion of the building to the extent that affects its entirety, and not only separate parts, is favored by economic and social factors. Properties with old buildings are located in city centers, where the land rent is higher. The increasing age of buildings weakens the sentimental attitude of the owners to their premises. Economic entities can, in such conditions, much more easily take over the entire building or a group of buildings to perform comprehensive restoration and resale or rent on a commercial basis. It is probable that the passage of time will have the same effect on architecture from the socialist realism period.

Author Contributions: Conceptualization, M.P., Ł.B. and E.G.; methodology, M.P.; validation, M.P., Ł.B. and E.G.; formal analysis, M.P.; investigation, M.P., Ł.B. and E.G.; resources, M.P., Ł.B.; writingoriginal draft preparation, M.P.; writing—review and editing, M.P.; visualization, Ł.B., E.G.; supervision, M.P. All authors have read and agreed to the published version of the manuscript.

Funding: This research received no external funding.

Conflicts of Interest: The authors declare no conflict of interest.

\section{References}

1. Hirt, S.; Stanilov, K. Twenty Years of Transition: The Evolution of Urban Planning in Eastern Europe and the Former Soviet Union, 1989-2009; UN-HABITAT: Nairobi, Kenya, 2009.

2. World Economic Forum. Making Affordable Housing a Reality in Cities; World Economic Forum: Geneva, Switzerland, 2019.

3. Aernouts, N.; Marranghi, E.; Ryckewaert, M. (Eds.) The Regeneration of Large-Scale Social Housing Estates. Spatial, Territorial, Institutional and Planning Dimensions; Soholab: Brussels, Belgium, 2020.

4. Cymer, A. Architektura w Polsce 1945-1989; Centrum Architektury, Narodowy Instytut Architektury i Urbanistyki: Warszawa, Poland, 2019.

5. Mazur, R. Dobra Kontynuacja; Oficyna Wydawnicza Politechniki Rzeszowskiej: Rzeszów, Poland, 2019. 
6. Nowicki, J. Budownictwo mieszkaniowe-osiedlowe. In Budownictwo i Architektura w Polsce 1945-1966; Zachwatowicz, J., Ed.; Wydawnictwo Interpress: Warszawa, Poland, 1968; pp. 36-47.

7. Zarządzenie Ministra Gospodarki Komunalnej z dnia 8 marca 1951 roku w sprawie zasad ustalania norm zaludnienia mieszkań. (Monitor Polski Nr A-24, Poz. 314). Available online: http:/ / isap.sejm.gov.pl/isap.nsf/download.xsp/WMP19510240314/O/M1 9510314.pdf (accessed on 25 October 2021).

8. Uchwała nr 70 Prezydium Rządu z dnia 6 lutego 1954 r. w sprawie zatwierdzenia normatywów projektowania dla budownictwa. mieszkaniowego (Monitor Polski Nr 120, Poz. 1688). Available online: http:/ /isap.sejm.gov.pl/isap.nsf/download.xsp/WMP195 41201688/O/M19541688.pdf (accessed on 25 October 2021).

9. Rocznik Statystyczny 1955; Główny Urząd Statystyczny: Warszawa, Poland, 1956.

10. Kotarbiński, A. Rozwój Urbanistyki i Architektury Polskiej w Latach 1944-1964. Próba Charakterystyki Krytycznej; Państwowe Wydawnictwo Naukowe: Warszawa, Poland, 1967.

11. Rocznik Statystyczny 2020; Główny Urząd Statystyczny: Warszawa, Poland, 2021.

12. Żarski, T. Budownictwo Mieszkaniowe w Polsce w Latach 1950-1965; Państwowe Wydawnictwo Ekonomiczne: Warszawa, Poland, 1966.

13. Sendi, R.; Kerbler, B. The Evolution of Multifamily Housing: Post-Second World War Large Housing Estates versus Post-Socialist Multifamily Housing Types in Slovenia. Sustainability 2021, 13, 10363. [CrossRef]

14. Ustawa z dnia 29 kwietnia 1985 r. o gospodarce gruntami i wywłaszczaniu nieruchomości. Dz. U. 1985, 22, 99 .

15. Zaniewska, H.; Dabkowski, N.; Thiel, M. Budownictwo mieszkaniowe z udziałem środków publicznych w gminach. Probl. Rozw. Miast. Kwart. Nauk. Inst. Rozw. Miast 2014, 4, 49-57.

16. Ustawa z dnia 20 lipca 2018 r. o przekształceniu prawa użytkowania wieczystego gruntów zabudowanych na cele mieszkaniowe w prawo własności tych gruntów. Dz. U. 2018, 1716.

17. The State of Housing in Europe 2021. Available online: https://www.stateofhousing.eu/The_State_of_Housing_in_the_EU_2021 .pdf (accessed on 25 October 2021).

18. Housing in Europe. Available online: https:/ / ec.europa.eu/eurostat/cache/digpub/housing (accessed on 25 October 2021).

19. Nedučin, D.; Škorić, M.; Krklješ, M. Post-socialist Development and Rehabilitation of Large Housing Estates in Central and Eastern Europe: A Review. Tech. Gaz. 2009, 26, 1853-1860.

20. Tofiluk, A.; Knyziak, P.; Krentowski, J. Revitalization of Twentieth-Century Prefabricated Housing Estates as Interdisciplinary Issue. Mater. Sci. Eng. 2019, 471, 112096. [CrossRef]

21. Zaniewska, H. Architektoniczno-urbanistyczne i społeczne aspekty dostosowania powojennej zabudowy osiedlowej do standardów XXI wieku. Przegląd Bud. 2013, 3, 145-148.

22. Kosiura, M.; Kłodaś, A.; Kaczyńska, D. Revitalization \& Modernization in Poland; Inicjatywa Drugie Życie Budynków: Warszawa, Poland, 2018.

23. Jakóbczyk-Gryszkiewicz, J.; Sztybel-Boberek, M.; Wolaniuk, A. Post-socialist Gentrification Processes in Polish Cities. Eur. Spat. Res. Policy 2017, 24, 145-166. [CrossRef]

24. Nickayin, S.; Halbac-Cotoara-Zanfir, R.; Clemente, M.; Chelli, F.; Salvati, L.; Benassi, F.; Morera, A. “Qualifying Peripheries” or "Repolarizing the Center": A Comparison of Gentrification Processes in Europe. Sustainability 2020, 12, 9039. [CrossRef]

25. Szczerek, E. Rewitalizacja Osiedli Wielkoptytowych a Ciagłość i Komplementarność Przestrzeni Publicznej Miasta; Politechnika Krakowska im. Tadeusza Kościuszki: Kraków, Poland, 2018.

26. Szafrańska, E. Transformations of Large Housing Estates in Central and Eastern Europe after the Collapse of Communism. Geogr. Pol. 2015, 88, 621-648. [CrossRef]

27. Trumbull, N.S. Restructuring socialist housing estates and its impact on residents' perceptions: "Renovatsiia" of khrushchevki in St. Petersburg, Russia. GeoJournal 2014, 79, 495-511. [CrossRef]

28. Phuong, D.Q. (Re)developing old apartment blocks in Hanoi: Government vision, local resistance and spatial routines. J. Asian Archit. Build. Eng. 2019, 18, 311-323. [CrossRef]

29. Przesmycka, E.; Napieralska, Z. Residential districts of the socialist realism period in Poland (1949-1956). Analysis, comparison and protection. Teka Kom. Archit. Urban. Studiów Kraj. Oddziału Pol. Akad. Nauk. Lub. 2020, 3, 7-18.

30. Sumorok, A. The idea of the socialist city. The case of Nowa Huta. Tech. Trans. Archit. 2015, 12-A, 303-340.

31. Lewicki, J. Assessing the value of the modernist epoch monuments. Past, present and future. J. Herit. Conserv. 2017, 49, 38-50.

32. Jacobs, J. The Death and Life of Great American Cities; Vintage Books: New York, NY, USA, 1961.

33. Alexander, C. A Pattern Language. Towns-Buildings-Constructions; Oxford University Press: New York, NY, USA, 1977.

34. Gehl, J. Life between Buildings. Using Public Space; Island Press: Washington, DC, USA; Covelo, CA, USA; London, UK, 2011.

35. The New Charter of Athens 1998. Available online: http:/ / www.planum.net/document-0 (accessed on 25 October 2021).

36. The New Charter of Athens 2003. Available online: https:// patterns.architexturez.net/doc/az-cf-172768 (accessed on 25 October 2021).

37. Report of the World Commission on Environment and Development: Our Common Future. Available online: https:// sustainabledevelopment.un.org/content/documents/5987our-common-future.pdf (accessed on 25 October 2021).

38. Kahn, A. Sustainable Development: The Key Concepts, Issues and Implications. Sustain. Dev. 1995, 3, $63-69$.

39. Lehmann, S. Green Urbanism: Formulating a Series of Holistic Principles. Surv. Perspect. Integr. Environ. Soc. 2010, 3, 1-10.

40. Lami, I.; Mecca, B. Assesing Social Sustainability for Achieving Sustainable Architecture. Sustainability 2021, 13, 142. [CrossRef] 
41. Eizenberg, E.; Jabareen, Y. Social Sustainability: A New Conceptual Framework. Sustainability 2017, 9, 68. [CrossRef]

42. Rudlin, D.; Falk, N. Sustainable Urban Neighbourhood. Building the 21st Century Home; Architectural Press: Oxford, UK, 1999.

43. Nasr, J.; Komisar, J.; de Zeeuw, H. A Panorama of Rooftop Agriculture Types. In Rooftop Urban Agriculture; Orsini, F., Dubbeling, M., de Zeeuw, H., Gianquinto, G., Eds.; Springer International Publishing: Cham, Switzerland, 2017; pp. 9-30.

44. Caputo, S.; Iglesias, P.; Rumble, H. Elements of Rooftop Agriculture Design. In Rooftop Urban Agriculture; Orsini, F., Dubbeling, M., de Zeeuw, H., Gianquinto, G., Eds.; Springer International Publishing: Cham, Switzerland, 2017; pp. 39-60.

45. Naranjo, A.; Colonia, A.; Mesa, J.; Maury, H.; Maury-Ramirez, A. State-of-the-Art Green Roofs: Technical Performance and Certifications for Sustainable Construction. Coatings 2020, 10, 69. [CrossRef]

46. Chidambaram, C.; Nath, S.S.; Varshney, P.; Kumar, S. Assessment of terrace gardens as modifiers of building microclimate. Energy Built Environ. 2021. [CrossRef]

47. Gorgolewski, M.; Straka, V. Integrating Rooftop Agriculture into Urban Infrastructure. In Rooftop Urban Agriculture; Orsini, F., Dubbeling, M., de Zeeuw, H., Gianquinto, G., Eds.; Springer International Publishing: Cham, Switzerland, 2017 ; pp. 113-126.

48. Harada, Y.; Whitlow, T.H. Urban Rooftop Agriculture: Challenges to Science and Practice. Front. Sustain. Food Syst. 2020, 4, 76. [CrossRef]

49. Rodriguez, O. London Rooftop Agriculture a Preliminary Estimate of London's Productive Potential. Master's Thesis, Wels School of Architecture, Cardiff, UK, 2009.

50. Rodríguez-Delfín, A.; Gruda, N.; Eigenbrod, C.; Orsini, F.; Gianquinto, G. Soil Based and Simplified Hydroponics Rooftop Gardens. In Rooftop Urban Agriculture; Orsini, F., Dubbeling, M., de Zeeuw, H., Gianquinto, G., Eds.; Springer International Publishing: Cham, Switzerland, 2017; pp. 61-82.

51. Milanovic, D.; Djuric-Mijovic, D.; Savic, J. Green roofs as a model of re-using flat roofs. In Proceedings of the 2nd International Conference on Urban Planning, Nis, Serbia, 14-17 November 2018; pp. 261-268.

52. Reimagining Spaces: Interconnection of Multi-Family Common Spaces. Available online: https://omgivning.com/journal/ commonspace-amenities-wfh-rooftop-skyline-urbanfarming/ (accessed on 25 October 2021).

53. Knaus, M.; Haase, D. Green roof effects on daytime heat in a prefabricated residential neighbourhood in Berlin, Germany. Urban For. Urban Green. 2020, 53, 126738. [CrossRef]

54. Orsini, F.; Pennisi, G.; Michelon, N.; Minelli, A.; Bazzocchi, G.; Sanyé-Mengual, E.; Gianquinto, G. Features and Functions of Multifunctional Urban Agriculture in the Global North: A Review. Front. Sustain. Food Syst. 2020, 4, 562513. [CrossRef]

55. Haase, D.; Kabisch, S.; Haase, A.; Andersson, E.; Banzhaf, E.; Baró, F.; Brenck, M.; Fischer, L.K.; Frantzeskaki, N.; Kabisch, N.; et al. Greening cities-To be socially inclusive? About the alleged paradox of society and ecology in cities. Habitat Int. 2017, 64, 41-48. [CrossRef]

56. Sattler, S.; Zluwa, I.; Österreicher, D. The "PV Rooftop Garden": Providing Recreational Green Roofs and Renewable Energy as a Multifunctional System within One Surface Area. Appl. Sci. 2020, 10, 1791. [CrossRef]

57. ML System. Available online: https://mlsystem.pl/ (accessed on 25 October 2021).

58. Zhang, X.; Lau, S.-K.; Lau, S.S.Y.; Zhao, Y. Photovoltaic integrated shading devices. Sol. Energy 2018, 170, 947-968. [CrossRef]

59. Jelle, B.P. Building Integrated Photovoltaics: A Concise Description of the Current State of the Art and Possible Researche Pathways. Energies 2016, 9, 21. [CrossRef]

60. Rosa, F. Building-Integrated Photovoltaics (BIPV) in Historical Buildings: Opportunities and Constraints. Energies 2020, $13,3628$. [CrossRef]

61. Gminna Ewidencja Zabytków Miasta Rzeszowa. Available online: https://bip.erzeszow.pl/static/img/k02/MKZ/GEZ/GEZ_ AKTUALNY_06.07.2021.pdf (accessed on 25 October 2021).

62. Projekt techniczny budynku mieszkalnego w Rzeszowie, Archiwum Państwowe w Rzeszowie, Sygn. 59/211/0/18/2869.

63. Projekt techniczny budynku mieszkalnego w Rzeszowie, Archiwum Państwowe w Rzeszowie, Sygn. 59/211/0/18/2867.

64. Projekt techniczny budynku mieszkalnego w Rzeszowie, Archiwum Państwowe w Rzeszowie, Sygn. 59/211/0/18/2868.

65. Popielas, T. Dobudowa Dźwigów Osobowych w Modernizowanych Budynkach Mieszkalnych WIelorodzinnych. Available online: https: / inzynierbudownictwa.pl/dobudowa-dzwigow-osobowych-w-modernizowanych-budynkach-mieszkalnychwielorodzinnych/ (accessed on 25 October 2021).

66. Extra Energy. Available online: https://www.extra-energy.pl/ (accessed on 25 October 2021).

67. Greg, W. Ocieplanie ścian Trójwarstwowych piana Poliuretanowa. Available online: https://muratordom.pl/remont-domu/ termomodernizacja / ocieplanie-scian-trojwarstwowych-piana-poliuretanowa-aa-349x-1nFC-XNjz.html (accessed on 25 October 2021).

68. Soikekeli, A. Additional floors in old apartment blocks. Energy Procedia 2016, 96, 815-823. [CrossRef]

69. Podsiadło, R. Rewitalizacja starych budynków wielopiętrowych. Przegląd Bud. 2006, 4, $23-25$.

70. Tomkowicz, B. Przekształcenia Przestrzeni Dachów. Ph.D. Thesis, Politechnika Krakowska im. Tadeusza Kościuszki, Kraków, Poland, 2019.

71. Rozporządzenie Ministra Infrastruktury z dnia 12 Kwietnia 2002r. w Sprawie Warunków Technicznych, Jakim Powinny Odpowiadać Budynki i ich Usytuowanie. Dz. U. 2015, 1422. Available online: https://isap.sejm.gov.pl/isap.nsf/DocDetails.xsp? id=WDU20020750690 (accessed on 25 October 2021).

72. Rozporządzenie Ministra Pracy i Polityki Socjalnej w sprawie ogólnych przepisów bezpieczeństwa i higieny pracy. Dz. U. 2003, 1650 . 
73. Slim Floor. Available online: https://sections.arcelormittal.com/products_and_solutions/Our_Specialties/Slim_floor/EN (accessed on 25 October 2021).

74. Farby fotokatalityczne-czym są i jakie mają zastosowanie? Na czym polega innowacja? Available online: https: / / www.muratorplus.pl/technika/chemia-budowlana/farby-fotokatalityczne-fenomen-na-rynku-farb-czym-sa-i-jakiemaja-zastosowanie-farby-fotokatalityczne-aa-8Dy9-qziZ-ngUV.html (accessed on 25 October 2021).

75. Sim, D. Soft City. Building Density for Everyday Life; Island Press: Washington, DC, USA; Covelo, CA, USA; London, UK, 2019.

76. Mochocka, S. Rehabilitacja Przestrzeni Kieleckich Osiedli Mieszkaniowych z lat 1960-1990 pod Kątem Współczesnych Potrzeb. Ph.D. Thesis, Politechnika Krakowska im. Tadeusza Kościuszki, Kraków, Poland, 2019.

77. Andrews, K.D.; Sendi, R. Large Housing Estates in Slovenia: A Framework for Renewal. Int. J. Hous. Policy 2001, 1, $233-255$. [CrossRef]

78. Lucchi, E.; Delera, A.C. Enhancing the Historic Public Social Housing through a User-Centered Design-Driven Approach. Buildings 2020, 10, 159. [CrossRef] 